\title{
Hydrological drought types in cold climates: quantitative analysis of causing factors and qualitative survey of impacts
}

\author{
A. F. Van Loon ${ }^{1,2}$, S. W. Ploum ${ }^{1}$, J. Parajka ${ }^{3}$, A. K. Fleig ${ }^{4}$, E. Garnier ${ }^{5,6}$, G. Laaha ${ }^{7}$, and H. A. J. Van Lanen ${ }^{1}$ \\ ${ }^{1}$ Hydrology and Quantitative Water Management Group, Wageningen University, P.O. Box 47, 6700 AA, \\ Wageningen, the Netherlands \\ ${ }^{2}$ School of Geography, Earth and Environmental Sciences, University of Birmingham, Edgbaston, Birmingham, B15 2TT, UK \\ ${ }^{3}$ Institute of Hydraulic Engineering and Water Resources Management, Vienna University of Technology, Vienna, Austria \\ ${ }^{4}$ Norwegian Water Resources and Energy Directorate, Oslo, Norway \\ ${ }^{5}$ CNRS UMR LIENSs-University of La Rochelle, La Rochelle, France \\ ${ }^{6}$ Institut Universitaire de France, Paris, France \\ ${ }^{7}$ Institute of Applied Statistics and Computing, University of Natural Resources and Life Sciences, Vienna, Austria
}

Correspondence to: A. F. Van Loon (a.f.vanloon@bham.ac.uk)

Received: 9 September 2014 - Published in Hydrol. Earth Syst. Sci. Discuss.: 19 September 2014

Revised: 24 February 2015 - Accepted: 29 March 2015 - Published: 24 April 2015

\begin{abstract}
For drought management and prediction, knowledge of causing factors and socio-economic impacts of hydrological droughts is crucial. Propagation of meteorological conditions in the hydrological cycle results in different hydrological drought types that require separate analysis. In addition to the existing hydrological drought typology, we here define two new drought types related to snow and ice. A snowmelt drought is a deficiency in the snowmelt discharge peak in spring in snow-influenced basins and a glaciermelt drought is a deficiency in the glaciermelt discharge peak in summer in glacierised basins. In 21 catchments in Austria and Norway we studied the meteorological conditions in the seasons preceding and at the time of snowmelt and glaciermelt drought events. Snowmelt droughts in Norway were mainly controlled by below-average winter precipitation, while in Austria both temperature and precipitation played a role. For glaciermelt droughts, the effect of below-average summer air temperature was dominant, both in Austria and Norway. Subsequently, we investigated the impacts of temperature-related drought types (i.e. snowmelt and glaciermelt drought, but also cold and warm snow season drought and rain-to-snow-season drought). In historical archives and drought databases for the US and Europe many impacts were found that can be attributed to these temperature-related hydrological drought types, mainly in the agriculture and electricity production (hydropower) sec-
\end{abstract}

tors. However, drawing conclusions on the frequency of occurrence of different drought types from reported impacts is difficult, mainly because of reporting biases and the inevitably limited spatial and temporal scales of the information. Finally, this study shows that complete integration of quantitative analysis of causing factors and qualitative analysis of impacts of temperature-related droughts is not yet possible. Analysis of selected events, however, points out that it can be a promising research area if more data on drought impacts become available.

\section{Introduction}

Socio-economic and ecological impacts of severe drought events (e.g. crop loss, wildfires, lack of drinking water, power shortage) are not directly related to meteorological drought, but indirectly, when persistent anomalous atmospheric conditions trigger soil moisture drought and hydrological drought (Fig. 1) (Wilhite and Glantz, 1985; Wilhite, 2000; Tallaksen and Van Lanen, 2004; Mishra and Singh, 2010). Therefore, besides good predictions of the meteorological situation, knowledge of the propagation of drought through the terrestrial hydrological cycle is crucial for drought management. Hydrological drought (drought in (sub)surface water storages and fluxes) can develop as a re- 


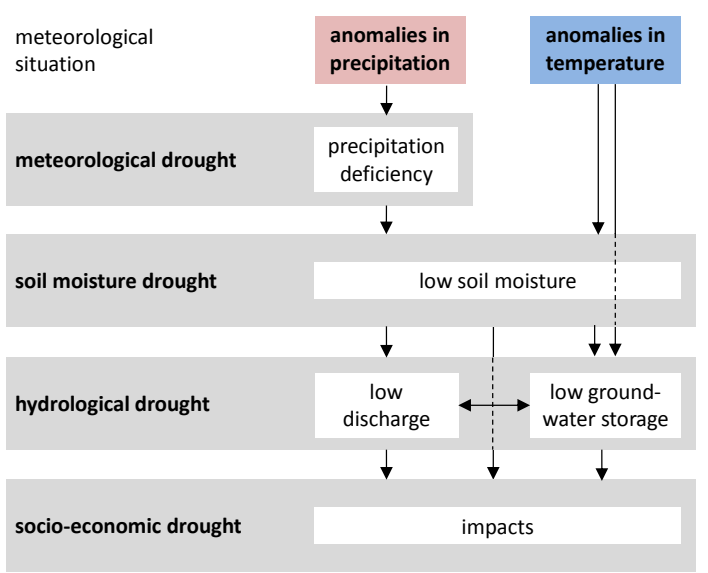

Figure 1. Scheme representing drought propagation (adapted from Fig. 8.1 of Van Loon, 2013).

sult of different processes (Fig. 1). These processes vary between regions with different climate and catchment characteristics. For example, in regions with high storage in aquifers, lakes and wetlands, many small meteorological drought events can grow together into a multi-year hydrological drought event, and in regions with cold climates, in which snow accumulation plays an important role in the seasonal hydrological cycle, anomalies in air temperature also influence hydrological drought development and recovery.

It is important to take these different drought propagation processes into account in statistical drought analysis, hydrological drought prediction and drought management. A hydrological drought typology is a useful tool because it classifies these processes and quantifies the relative influence of these processes in a specific drought event or in a specific catchment. Van Loon and Van Lanen (2012) distinguished six hydrological drought types (further called HDTs for brevity) by studying drought propagation processes in five contrasting catchments. These are classical rainfall deficit drought, rain-to-snow-season drought, wet-todry-season drought, cold snow season drought, warm snow season drought and composite drought. For some HDTs, anomalies in precipitation are the driver of the hydrological drought development (rainfall deficit drought, rain-to-snowseason drought, wet-to-dry-season drought), and for some HDTs, anomalies in air temperature play a more prominent role (cold snow season drought, warm snow season drought).

In Van Loon and Van Lanen (2012), we speculated that there might be other HDTs in climate zones that were not studied. Van Loon and Laaha (2014) applied the hydrological drought typology to a selection of catchments in Austria, testing this hypothesis, and discovered hydrological drought events that could not be explained by any of the processes in the existing typology. These unknown drought types were found in catchments with a pronounced influence of snow and glaciers on the hydrological regime.
In this paper we define two new HDTs in cold climates and investigate their underlying processes and their socioeconomic impacts. We compare drought propagation processes between different regions with cold climates (the Alpine region and Scandinavia). Furthermore, we present an extensive search for impacts of temperature-related hydrological droughts from a collection of different sources (drought impact databases and historical archives). According to our knowledge this is the first time that such an analysis of temperature-related droughts is presented, including a theoretical description, quantitative analysis of causing factors, and a more generic qualitative analysis of socioeconomic impacts.

For this research, we have two hypotheses, namely (1) that for each region, the occurrence and severity of the new HDTs can be related to meteorological causing factors in specific seasons, and (2) that HDTs in cold climates have had socioeconomic impacts in the recent and distant past. After presenting the theory of both the existing and new temperaturerelated HDTs (Sect. 2), we first investigate hypothesis 1 by quantitatively analysing causing factors of these new HDTs in a number of catchments from two selected study areas (Sect. 3). Hypothesis 2 is investigated by qualitatively studying socio-economic impacts of temperature-related HDTs in the US and Europe in Sect. 4. In Sects. 5 and 6, both the quantitative and qualitative analyses are discussed and summarised.

\section{Temperature-related drought types: theory}

The hydrological drought typology, developed by Van Loon and Van Lanen (2012), includes three HDTs that are governed by temperature control (Fig. 2 and Table 1, upper part). For a selection of Austrian catchments, Van Loon and Laaha (2014) found severe deficits in the high-flow period: in spring in catchments with a clear snowmelt peak and in summer in catchments with a high percentage of glaciers. This led us to define two new HDTs, namely snowmelt drought and glaciermelt drought (Table 1, lower part). The main characteristics of all HDTs related to temperature control and snow and ice accumulation and melt are summarised in the following sections.

\subsection{Rain-to-snow-season drought}

According to Van Loon and Van Lanen (2012), rain-to-snowseason drought is one of the most severe drought types in snow-dominated regions. It develops as a rainfall deficit drought in summer or autumn, but air temperatures drop below zero before full recovery (Fig. 2a). Consequently, the drought continues throughout winter, the normal low-flow period, resulting in critical reservoir levels and groundwater levels by the end of winter. 
Table 1. Drought propagation processes (including development and recovery) per temperature-related hydrological drought type and subtype (adapted from Table 8.1 of Van Loon, 2013, and including new types). $P=$ precipitation and $T=$ air temperature.

\begin{tabular}{lllc}
\hline Hydrological drought type (HDT) & Governing process(es) & Development & (Lack of) recovery \\
\hline Rain-to-snow-season drought & Rainfall deficit in rain season, drought continues into snow season & $P$ control & $T$ control \\
Cold snow season drought & Low temperature in snow season, leading to & $T$ control & $T$ control \\
Subtype A & Early beginning of snow season & $T$ control & $T$ control \\
Subtype B & Delayed snowmelt & $T$ control & $T$ control \\
Subtype C & No recharge & $T$ control & $P$ control \\
Warm snow season drought & High temperature in snow season, leading to & $P$ and $T$ control & $P$ control \\
Subtype A & Early snowmelt & $P$ and/or $T$ control $P$ control \\
Subtype B & In combination with rainfall deficit, no recharge & $T$ control & $P$ and/or $T$ control \\
\hline Snowmelt drought & Lack of snowmelt in snowmelt season & &
\end{tabular}

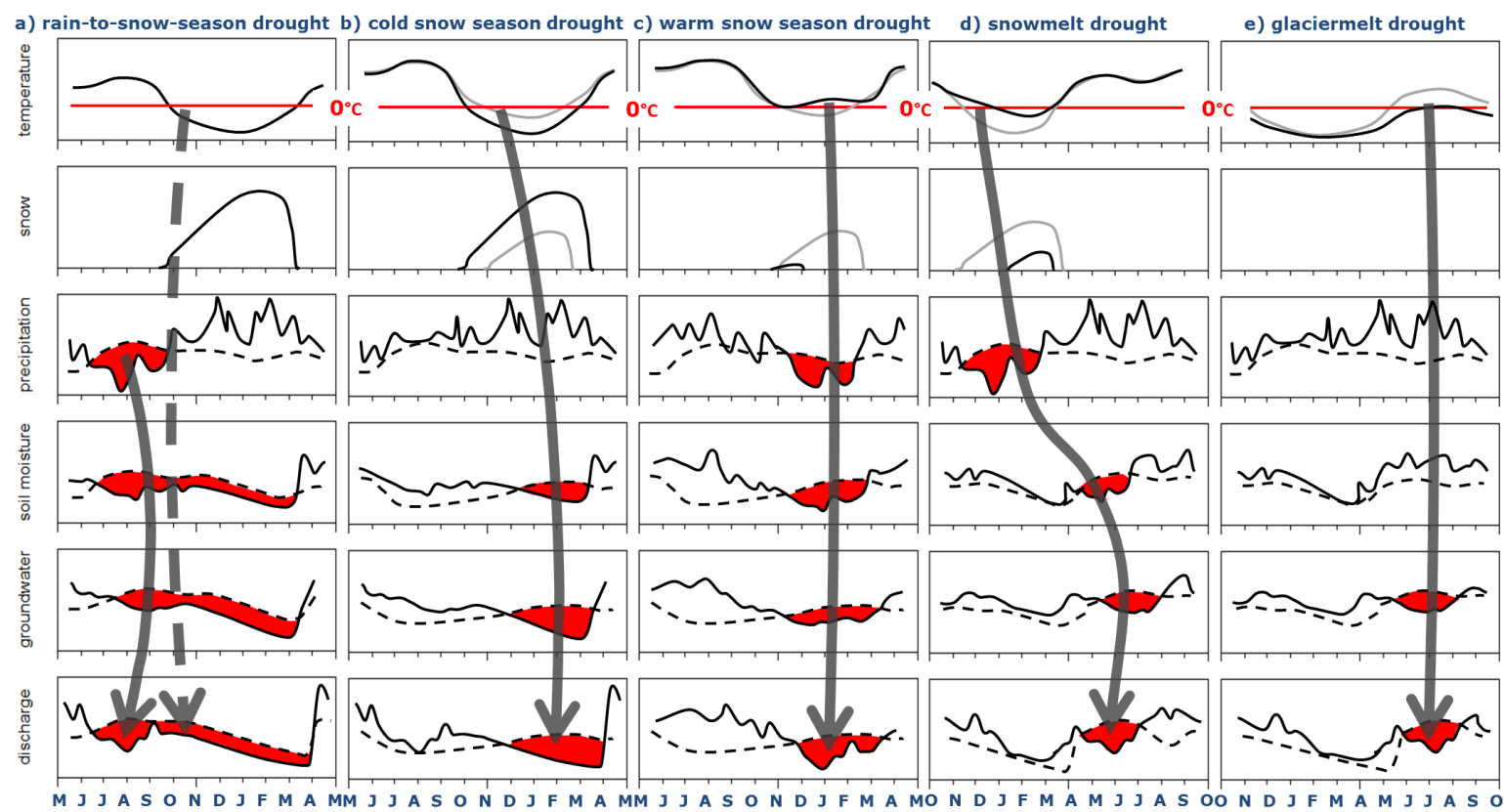

Figure 2. Synthetic time series representing the propagation of a meteorological anomaly (precipitation and/or temperature) through the terrestrial hydrological cycle per hydrological drought type (HDT) (adapted from Fig. 8.2 of Van Loon, 2013, and including new HDTs). The black lines are the time series of each hydrometeorological variable, the grey lines in the upper two rows are long-term averages of air temperature and snow, the dashed lines represent the threshold levels, and the red surfaces indicate drought events. Propagation of drought events is indicated by the arrows; dashed arrows represent a lack of recovery of the hydrological drought (meteorological drought ceased). The cold snow season drought is subtype $C$ and the warm snow season drought is subtype B. For a description, see Table 1.

\subsection{Cold snow season drought}

Cold snow season droughts develop when winter air temperatures are consistently below normal (Van Loon and Van Lanen, 2012). Precipitation falls as snow and accumulates, preventing infiltration to the groundwater and runoff to streams. In climates with mild winters this influences water availability during the entire winter (subtype C; Table 1 and Fig. 2b). In climates with harsh winters only the beginning and end of winter are affected because air temperatures are normally below zero (subtypes A and B; Table 1).

\subsection{Warm snow season drought}

Warm snow season droughts are the opposite of cold snow season droughts. They develop when winter air temperatures are consistently above normal (Van Loon and Van Lanen, 2012). In mild winter climates, a hydrological drought during winter occurs due to a lack of both snowmelt and rainfall (subtype B; Table 1 and Fig. 2c). In harsh winter climates, a hydrological drought develops after an early snowmelt peak (subtype A; Table 1). 


\subsection{Snowmelt drought}

A snowmelt drought is characterised by a deficiency in the snowmelt discharge peak in spring in snow-influenced basins (Fig. 2d-lower panel). This deficiency is due to a lack of snow accumulation during winter (Fig. $2 \mathrm{~d}-$ second panel). In spring no distinct precipitation deficit occurs that can explain the discharge deficit (Fig. 2d - third panel). The processes resulting in deficiencies in snow accumulation during winter are, for example, a lack of precipitation during winter (Fig. 2d - third panel) or no buildup or partial melt of the snow cover due to high winter air temperatures (Fig. 2d upper panel). Consequently, the snowmelt peak is below normal or completely absent. Because discharges are normally high during the spring snowmelt season, deficit volumes of snowmelt droughts are generally high as well (Van Loon and Laaha, 2014).

Snowmelt droughts are multi-season droughts, because meteorological conditions in one season (winter) cause hydrological drought in another season (spring). This shows the difference from a classical rainfall deficit drought in which a precipitation deficit causes a hydrological drought directly or with a small lag (Van Loon and Van Lanen, 2012). In a snowmelt drought the influence of a precipitation deficit is delayed due to storage in the snow pack. Furthermore, the interaction between air temperature and precipitation plays an important role in determining snow accumulation, melt, refreezing, infiltration, runoff, etc.

A snowmelt drought differs from a cold snow season drought - type B (Table 1) in the sense that in the latter the snowmelt peak is only delayed and not lower than normal. Equally, in a warm snow season drought - type A (Table 1), the snowmelt peak is only advanced and not lower than normal.

\subsection{Glaciermelt drought}

A glaciermelt drought is characterised by a deficiency in the glaciermelt discharge peak in summer in glacierised basins (Fig. 2e - lower panel), which is not caused by a precipitation deficit of similar magnitude (Fig. 2e - third panel). The most probable explanation for a lack of glacial melt in summer is low summer air temperatures (Fig. 2e - upper panel). A deficit compared to the normal seasonal cycle can occur during the whole melt season or only during part of the melt season, for a longer or shorter period. Because discharges are normally high during the summer glaciermelt season, deficit volumes of glaciermelt droughts are generally high as well (Van Loon and Laaha, 2014), just as for the snowmelt drought.

In contrast to snowmelt drought, the glaciermelt drought is a within-season drought, because the meteorological conditions causing the drought and the drought event itself occur in the same season (summer). A glaciermelt drought can be confused with a cold snow season drought - type B, but a cold snow season drought is related to a delay of a (snow)melt peak, rather than a mutation of the (glacier)melt peak itself.

\section{Temperature-related drought types: causing factors}

Van Loon and Van Lanen (2012) investigated causing factors of the existing HDTs rain-to-snow-season drought, cold snow season drought and warm snow season drought in three contrasting European catchments. These causing factors can be summarised as follows:

- Rain-to-snow-season drought events were related to below-normal precipitation in the preceding summer and around-average or below-average air temperature in winter. In the case of above-average air temperature in winter, the hydrological drought would have terminated before the start of winter and would be defined as classical rainfall deficit drought (Van Loon and Van Lanen, 2012).

- Cold snow season drought events were caused by below-average air temperature in winter and aroundaverage or below-average precipitation in the preceding summer. In the case of above-average precipitation in summer, no hydrological drought developed, because antecedent moisture conditions were high enough (Van Loon and Van Lanen, 2012). Late snowmelt is one of the possible manifestations.

- Warm snow season drought events were caused by above-average air temperature in winter. If combined with below-average winter precipitation, they result in a hydrological drought in winter. If occurring at the end of winter, snowmelt is earlier, resulting in a hydrological drought in the following summer (Van Loon and Van Lanen, 2012).

In this section, we investigate the processes underlying the development of the newly defined HDT snowmelt drought and glaciermelt drought. We quantify the relative importance of different climate drivers ( $P$ and $T)$ in different seasons for the development of these drought types. In this section, we describe the data, methods and results of our quantitative analysis of the causing factors of snowmelt drought and glaciermelt drought in Austria and Norway.

\subsection{Study areas}

The 15 Austrian and 8 Norwegian catchments used in this study vary in climate and catchment characteristics (Fig. 3 and Table 2). The Austrian catchments were clustered according to geographical and thematic similarities by Gaál et al. (2012) and Haslinger et al. (2014) into four clusters, i.e. Gailtal, Mühlviertel, Hoalp and Ötztal. Gailtal and Mühlviertel are low Alpine and low mountain range clusters, respectively, with a distinct snowmelt discharge peak in spring. Average winter air temperatures are close to $0^{\circ} \mathrm{C}$ (respectively 
Table 2. Catchment characteristics of selected catchments in Austria and Norway, per cluster (min-max per catchment).

\begin{tabular}{|c|c|c|c|c|c|c|c|c|}
\hline $\begin{array}{l}\text { Cluster } \\
\text { (no. of catchments) } \\
-\end{array}$ & $\begin{array}{l}\text { Period } \\
\text { of sim. } \\
\quad-\end{array}$ & $\begin{array}{r}\text { Area } \\
\left(\mathrm{km}^{2}\right)\end{array}$ & $\begin{array}{r}\text { Elevation } \\
(\mathrm{m})\end{array}$ & $\begin{array}{r}\text { Mean annual air } \\
\text { temperature } \\
\left({ }^{\circ} \mathrm{C}\right)\end{array}$ & $\begin{array}{r}\text { Mean annual } \\
\text { precipitation } \\
(\mathrm{mm})\end{array}$ & $\begin{array}{r}\text { Glacier } \\
\text { cover } \\
(\%)\end{array}$ & $\begin{array}{r}\text { Mean duration } \\
\text { winter season } \\
\text { (days) }\end{array}$ & $\begin{array}{r}\text { Mean duration } \\
\text { spring season } \\
\text { (days) }\end{array}$ \\
\hline Gailtal (4) & $1976-2008$ & $140-940$ & $491-2734$ & $2.8-5.1$ & $1260-1430$ & 0 & 160 & 47 \\
\hline Hoalp (2) & $1976-2008$ & $40-65$ & $1494-3560$ & $-0.5-0.3$ & $1420-1430$ & $27-42$ & 177 & 32 \\
\hline Mühlviertel (4) & $1976-2008$ & $120-255$ & $496-1346$ & $7.0-7.4$ & $930-1120$ & 0 & 95 & 50 \\
\hline Ötztal (5) & $1976-2008$ & $60-785$ & $952-3770$ & $-2.2-0.6$ & $1090-1110$ & $17-43$ & 177 & 32 \\
\hline Glomma (4) & $1958-2013$ & $120-1830$ & $170-2460$ & $-3.1-1.7$ & $700-960$ & $0-12$ & 177 & 43 \\
\hline Central Norway (4) & $1958-2013$ & 24-235 & $50-2070$ & $-0.7-2.5$ & $2310-5270$ & $19-75$ & 178 & 32 \\
\hline
\end{tabular}

(a)
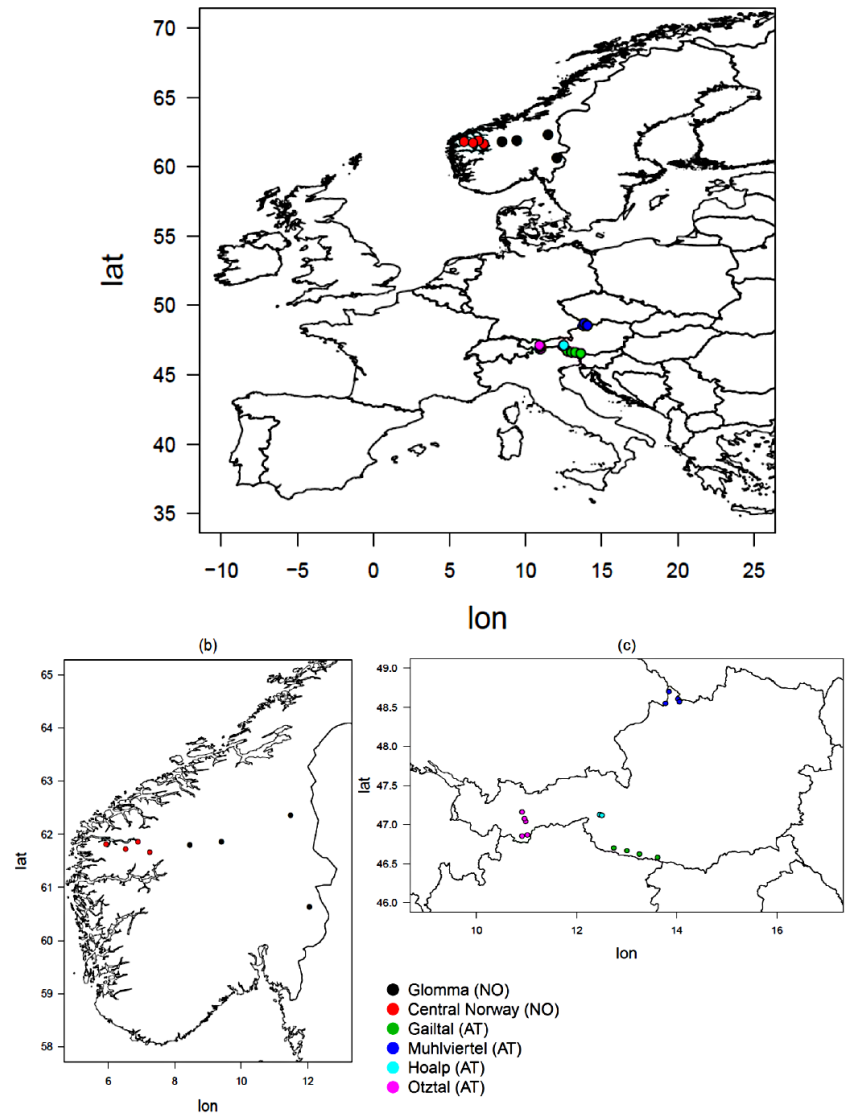

Figure 3. Selected catchments in Norway (b) and Austria (c).

-5 and $\left.-1{ }^{\circ} \mathrm{C}\right)$. Clusters Hoalp and Ötztal consist of steep, glaciated Alpine catchments with mainly summer discharge. In the Norwegian study area, four of the catchments are subcatchments of the Glomma basin in southeastern Norway, in a typical subarctic climate with short summers and long winters. Akslen is the only glacier-influenced catchment in this area. Other glacierised catchments in Norway are Lovatn, $\mathrm{Ni}$ gardsbrevatn, Gloppenelv, and Skjerdalselv. They are located in the mountainous regions of southwestern Norway. Glacier cover in the selected catchments ranges from 12 to $75 \%$ (Table 2).

\subsection{Data}

Observations of discharge $(Q)$, air temperature $(T)$ and precipitation $(P)$ were analysed for identification of possible key variables in snowmelt droughts and glaciermelt droughts. Daily $P$ and $T$ data were taken from a gridded data set, both in Norway (Mohr and Tveito, 2008) (available from www.senorge.no) and in Austria (Haslinger et al., 2014). The data were corrected for elevation differences between the grid cells and the catchment, in Norway by site-specific precipitation altitude gradients, determined by model calibration (Li et al., 2014), and in Austria by using elevation zones of $200 \mathrm{~m}$ and external drift kriging interpolation. Discharge time series in daily resolution were available from operational hydrological services, i.e. the Hydrographical Service of Austria (HZB) and the Norwegian Water Resources and Energy Directorate (NVE). In Austria, 1 out of 15 catchments had more than 1 year of missing discharge data. In Norway, this was three out of eight. The years with missing data were disregarded from further analysis for that specific catchment.

For snowmelt drought analysis in non-glaciated catchments, additional time series of snow water equivalent (SWE) from hydrological model simulations were used. Model simulations were obtained from a semi-distributed conceptual hydrological model, similar in structure to the HBV (Hydrologiska Byråns Vattenbalansavdelning) model (Bergström, 1995). For Austria, a version of the HBV model was used that is developed by the Technical University in Vienna. A detailed description of the structure of this model is presented in Parajka et al. (2007). Snow accumulation is determined by air temperature thresholds used for splitting precipitation into snowfall, rainfall and melt, where the rate of snowmelt is calculated by a simple degree-day approach. For calibration, a compound objective function was used consisting of three parts: (1) Nash-Sutcliffe (NSE), (2) NSE estimated from logarithmic transformed runoff values, and (3) an informed guess about the shape of the a priori distribution of model parameters. The model has been applied successfully in numerous regional studies in Austria in the past (e.g. Parajka and Blöschl, 2008; Merz et al., 2009). More details on the modelling set-up, model input preparation and automatic model calibration procedure used in this study are presented 

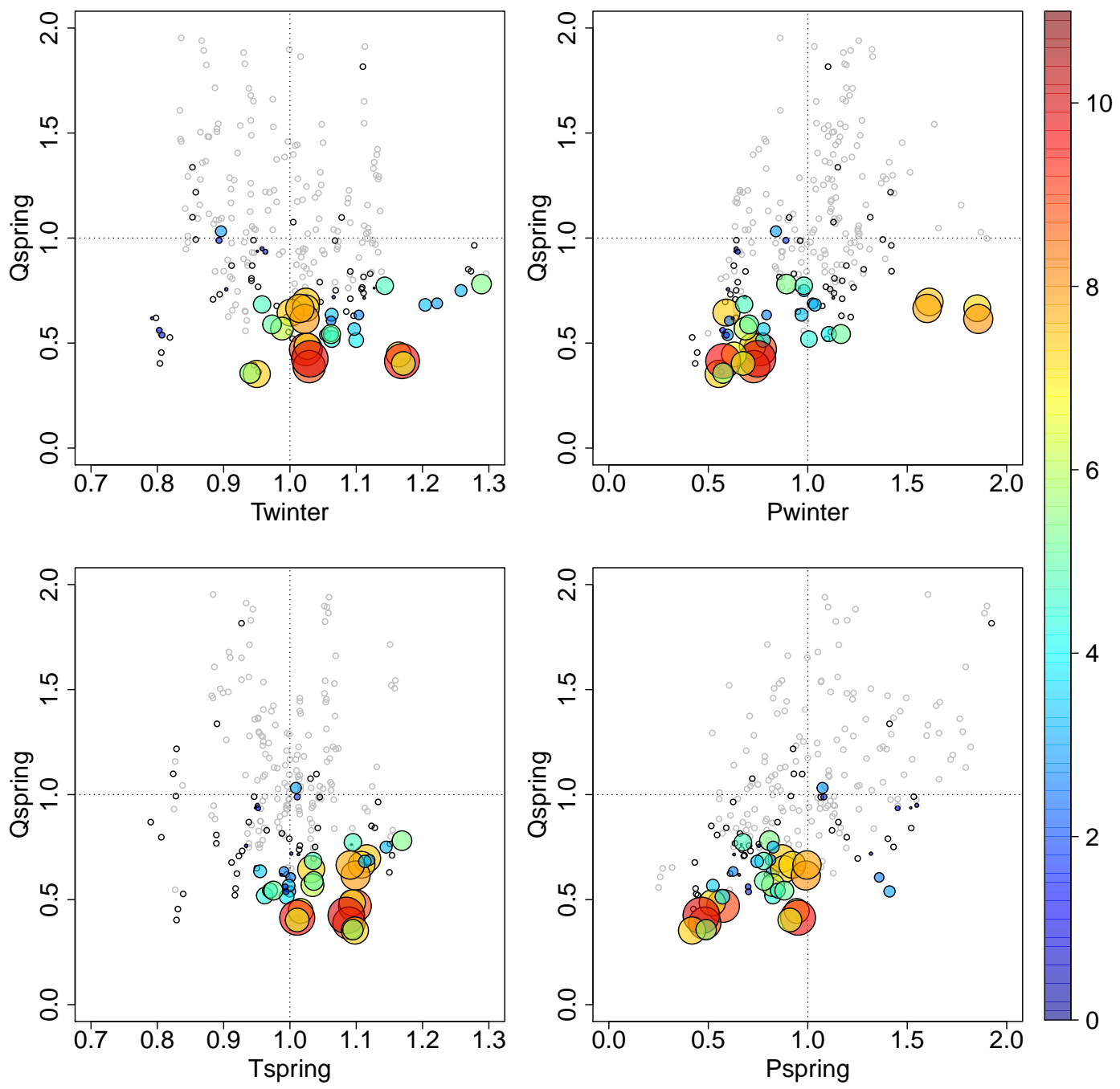

Figure 4. Snowmelt drought events in Austrian catchments: standardised spring discharge $\left(Q_{\text {spring }}\right)(-)$ against standardised causing factors $\left(T_{\text {winter }}, P_{\text {winter }}, T_{\text {spring }}, P_{\text {spring }}\right)(-)$. Below $1=$ below average; above $1=$ above average. Grey circles: all years; black circles: all drought years; coloured circles: snowmelt drought years (size and colour of dots are dependent on standardised drought deficit (-); scale on the right side of the figure).

in Merz et al. (2011). The Nash-Sutcliffe values for the Austrian catchments used in this study ranged from 0.6 to 0.9 , with an average of 0.8. Nash-Sutcliffe values based on the logarithm of discharge were even higher.

For Norway, the "Nordic" HBV version was applied (Sælthun, 1996; Beldring et al., 2003). Just as in the Austrian HBV version, snowfall is calculated when air temperature is below a threshold temperature and snowmelt is calculated with a degree-day approach. The "Nordic" HBV model was calibrated on the sum of squared differences between simulated and observed discharge using the PEST parameter optimisation software. Nash-Sutcliffe values for the Norwegian catchments used in this study ranged from 0.56 to 0.9 , with an average of 0.8 . Nash-Sutcliffe values based on the logarithm of discharge were slightly lower. In both HBV model versions, glaciers are not modelled explicitly, because no calibration or validation data of glaciers were available. Therefore, we could not use simulated data for glaciated catchments and only used simulated SWE in non-glaciated catchments. We did compare results based on observed discharge with those based on simulated discharge for both nonglaciated and glaciated catchments to evaluate how far off the models were (see Appendix A).

\subsection{Data analysis methods}

For the analysis of the causing factors of snowmelt droughts, anomalies in $P$ and $T$ in the snowmelt period and in the preceding snow accumulation period were needed and, for glaciermelt droughts, anomalies in $P$ and $T$ in the glaciermelt period and in the preceding snow accumulation period are relevant. The period of snow accumulation and 

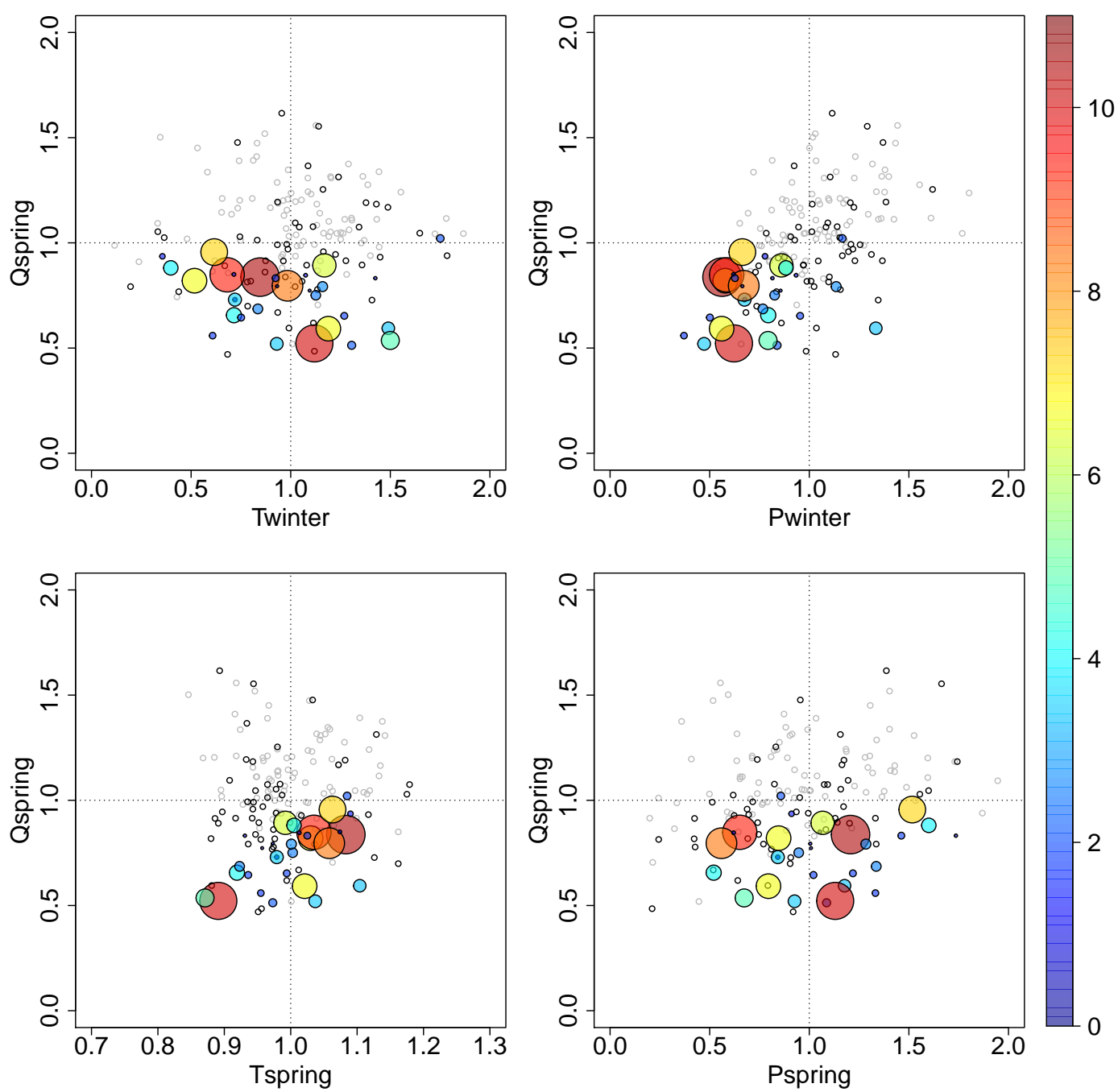

Figure 5. Snowmelt drought events in Norwegian catchments: standardised spring discharge $\left(Q_{\text {spring }}\right)(-)$ against standardised causing factors $\left(T_{\text {winter }}, P_{\text {winter }}, T_{\text {spring }}, P_{\text {spring }}\right)(-)$. Below $1=$ below average; above $1=$ above average. Grey circles: all years; black circles: all drought years; coloured circles: snowmelt drought years (size and colour of dots are dependent on standardised drought deficit (-); scale on the right side of the figure).

snowmelt/glaciermelt are highly variable between catchments, dependent on location (Fig. 3) and altitude (Table 2). Therefore, we defined the seasons per catchment based on long-term averages (regimes) for that specific catchment. In this way, the snow accumulation season is the period with below-zero air temperature (like in Feyen and Dankers, 2009) and positive snow accumulation. This season is further called "winter". For the snowmelt season, a similar approach was followed, starting at the end of winter (above-zero air temperature and negative snow accumulation) and ending after the melt peak in discharge (halfway on the recession curve of the discharge regime). This season is further called "spring". The glaciermelt season is difficult to define based on processes because in glacierised catchments the snowmelt peak and glaciermelt peak cannot be distinguished. Therefore, we chose to use the definition of meteorological sum- mer (June-July-August; JJA) for the glaciermelt period. This period we call "summer". This resulted in a start of winter between 11 October and 5 December, an end of winter and start of spring between 1 March and 8 May, and an end of spring between 20 April and 21 June. Winter duration was on average 160 days (95-209 days) and spring duration 40 days (24-57). Summer duration for all catchments was 92 days. More information on this selection procedure and the regime plots is given in Ploum and Van Loon (2014).

For all seasons, the precipitation sum (e.g. $\left.P_{\text {winter}}\right)$, air temperature average (e.g. $T_{\text {spring }}$ ), and discharge sum (e.g. $Q_{\text {summer }}$ ) were calculated. Additionally, for the winter season, maximum simulated snow accumulation $\left(\mathrm{SWE}_{\text {winter }}\right)$ and the number of days with air temperature above zero degrees (PlusZero) were calculated. To allow easy comparison between catchments, season sums and averages were stan- 

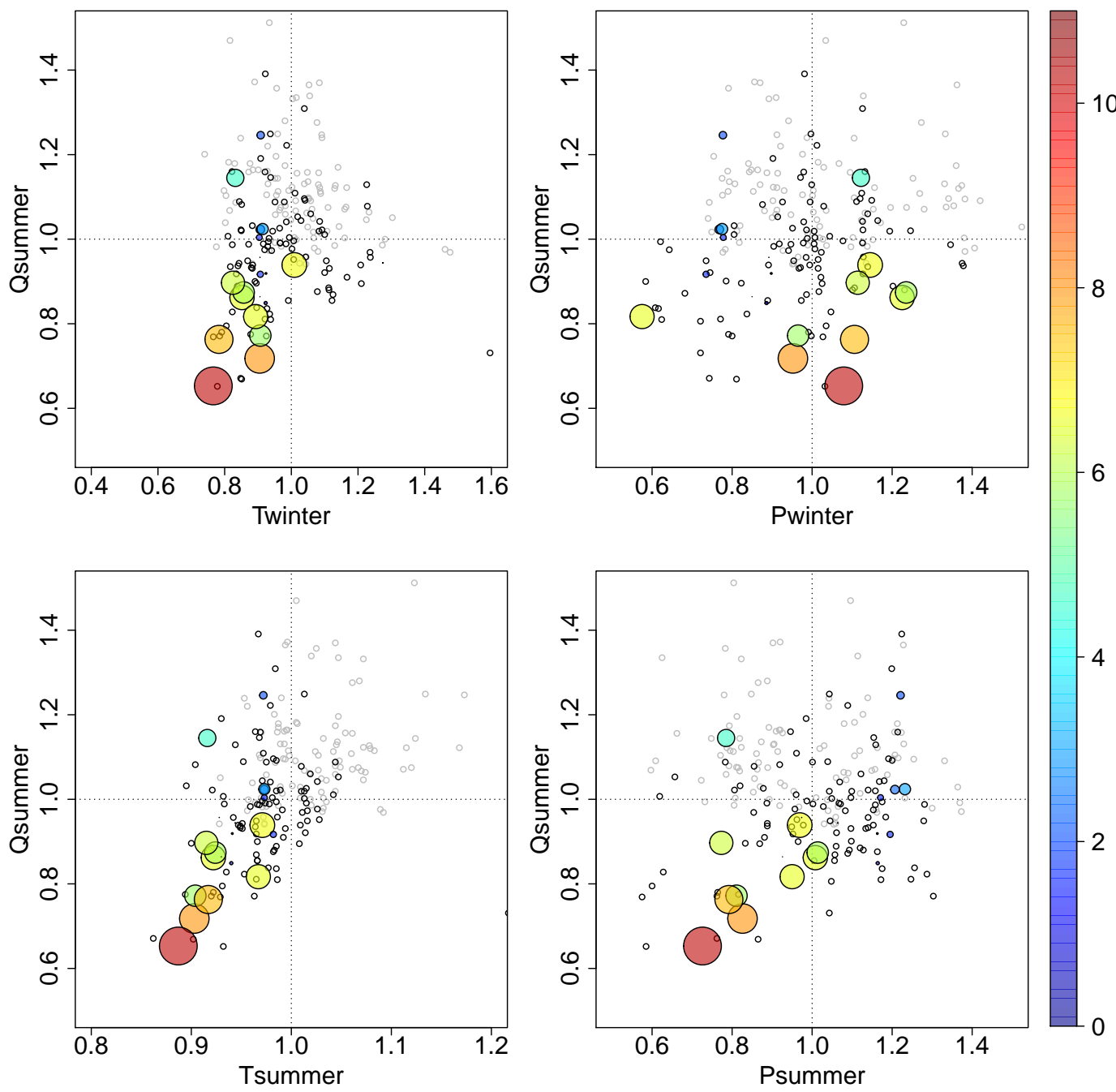

Figure 6. Glaciermelt drought events in Austrian catchments: standardised summer discharge ( $\left.Q_{\text {summer }}\right)(-)$ against standardised causing factors $\left(T_{\text {winter }}, P_{\text {winter }}, T_{\text {summer }}, P_{\text {summer }}\right)(-)$. Below $1=$ below average; above $1=$ above average. Grey circles: all years; black circles: all drought years; coloured circles: glaciermelt drought years (size and colour of dots are dependent on standardised drought deficit (-); scale on the right side of the figure).

dardised by dividing by the long-term mean of the variable for the specific catchment, resulting in dimensionless numbers with values around $1 . T$ data were systematically increased with $15^{\circ} \mathrm{C}$ before standardisation to avoid negative scales due to below zero winter averages and positive means or vice versa. Other scaling methods were tested, e.g. recalculating $T$ to Kelvin. This gave similar results in terms of correlation, but complicated visual inspection due to the compressed scale of anomalies.

For visual inspection, standardised spring and summer discharge ( $Q_{\text {spring }}$ and $Q_{\text {summer }}$ ) were plotted against standardised seasonal $T$ and $P$ including marked droughts. To quantify relations between discharge with a certain variable (e.g. $T_{\text {winter }}$ ), Pearson's correlations $R$ were calculated for each catchment and for each cluster of catchments (snowinfluenced and glacier-influenced catchments in Austria and
Norway). We also tested Spearman correlations, but that gave similar results.

From the time series of precipitation and discharge, we identified droughts with the widely used threshold level approach (Hisdal et al., 2004; Fleig et al., 2006; Van Loon, 2013), defining a drought when a variable falls below a predefined threshold. To reflect seasonality, we used a variable threshold based on the 80th percentile of the flow duration curve of a 30 day moving window (Beyene et al., 2014). In this way we defined drought as water availability below the normal seasonal cycle, so as a deficit during both low-flow and high-flow periods. This is consistent with $\mathrm{Vi}$ dal et al. (2010), Parry et al. (2012), and Prudhomme et al. (2014), but does not follow the terminology of Hisdal et al. (2004), who advised that "events defined with the varying threshold should be called streamflow deficiencies or stream- 

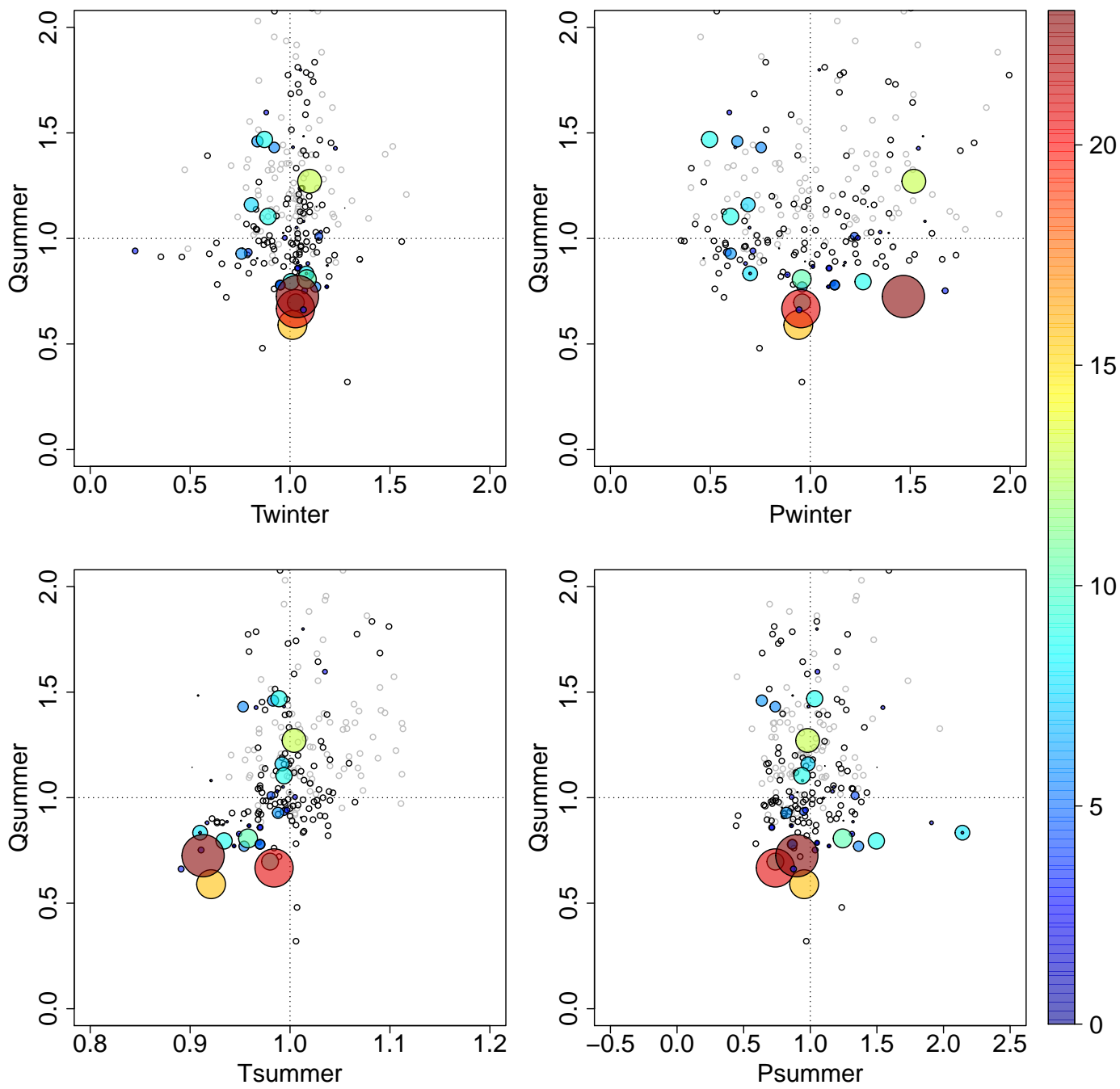

Figure 7. Glaciermelt drought events in Norwegian catchments: standardised summer discharge ( $\left.Q_{\text {summer }}\right)(-)$ against standardised causing factors $\left(T_{\text {winter }}, P_{\text {winter }}, T_{\text {summer }}, P_{\text {summer }}\right)(-)$. Below $1=$ below average; above $1=$ above average. Grey circles: all years; black circles: all drought years; coloured circles: glaciermelt drought years (size and colour of dots are dependent on standardised drought deficit (-); scale on the right side of the figure).

flow anomalies rather than streamflow droughts" (p. 166). Drought deficit was calculated with the sub-threshold volume (Van Loon, 2013) as a measure of the severity of an event. Drought deficit values were also standardised by dividing by mean drought deficit for the specific catchment.

We applied the typology of Van Loon and Van Lanen (2012), based on the time series of precipitation, air temperature, simulated snow and discharge for all catchments. Most of the drought events that could not be classified with the existing typology, were assigned to the new drought types snowmelt drought or glaciermelt drought based on the dominant propagation processes (Sect. 2 and Table 1 - lower part). A drought event was classified as snowmelt drought if the centre point of the drought was within the snowmelt period (spring) and no precipitation deficit in spring occurred with similar magnitude as the discharge deficit. A drought event was classified as glaciermelt drought if the centre point of the drought was within the glaciermelt period (summer) and no precipitation deficit in summer occurred with similar magnitude as the discharge deficit.

\subsection{Results}

In both Austrian and Norwegian catchments, most drought events (between 35 and $65 \%$ of all events per catchment) were classified as classical rainfall deficit drought, as was expected from the analysis in contrasting European catchments by Van Loon and Van Lanen (2012). No wet-to-dry-season drought was found, as seasonality in precipitation is negligible in these catchments compared to monsoon climates or Mediterranean climates. Rain-to-snow-season drought, cold snow season drought and warm snow season drought oc- 
Table 3. Correlation between $Q_{\text {spring }}$ and possible related meteorological factors for snowmelt drought and between $Q_{\text {summer }}$ and possible related meteorological factors for glaciermelt drought. Correlations above 0.5 are indicated in bold.

\begin{tabular}{lrrrr}
\hline & \multicolumn{4}{c}{ Hydrological variables } \\
\cline { 2 - 5 } Meteorological & $Q_{\text {spring }}$ & $Q_{\text {spring }}$ & $Q_{\text {summer }}$ & $Q_{\text {summer }}$ \\
variable & Austria & Norway & Austria & Norway \\
\hline$T_{\text {winter }}$ & -0.10 & -0.21 & 0.22 & -0.08 \\
$P_{\text {winter }}$ & 0.16 & 0.21 & -0.23 & -0.04 \\
SWE $_{\text {winter }}$ & -0.02 & -0.09 & & \\
PlusZero & -0.04 & -0.11 & & \\
$T_{\text {spring }}$ & -0.17 & $\mathbf{0 . 5 3}$ & & \\
$P_{\text {spring }}$ & $\mathbf{0 . 5 7}$ & 0.13 & & \\
$T_{\text {summer }}$ & & & $\mathbf{0 . 5 9}$ & 0.34 \\
$P_{\text {summer }}$ & & & $\mathbf{0 . 5 6}$ & -0.10 \\
\hline
\end{tabular}

curred in all catchments, on average about 9,8 and $6 \%$ of all drought events, respectively. The new HDT snowmelt drought occurred regularly in the Austrian clusters Gailtal and Mühlviertel and in the Norwegian Glomma catchments, ranging from $7 \%$ of all drought events in one of the Mühlviertel catchments up to $28 \%$ for one of the Glomma catchments, with an average of $13 \%$. Glaciermelt droughts occurred regularly in the Austrian clusters Hoalp and Ötztal and in the central Norwegian catchments; with percentages around $20 \%$, they were slightly more common than snowmelt droughts.

Visual analysis of scatter plots of observed discharge against possible causing factors (Figs. 4-7) revealed different patterns in Austria and Norway. Snowmelt droughts in Austria seem to be caused by a combination of factors (Fig. 4). For most events, winter air temperatures were above average (for about $70 \%$ of all snowmelt drought events), winter precipitation was below average (for about $75 \%$ ), spring air temperature was above average (for about $65 \%$ ), and spring precipitation was below average (for about $80 \%$ ). The most extreme events mainly cluster in the low winter precipitation graph (Fig. 4 - top right panel). Additionally, a clear orientation in precipitation is visible in all years (grey circles). This indicates that spring discharge decreases (increases) with decreasing (increasing) precipitation (winter and spring).

Snowmelt droughts in Norway show a different pattern (Fig. 5). The meteorological conditions in spring do not seem to have any influence on spring discharge or droughts in spring (Fig. 5 - lower panels). Half of the snowmelt droughts in Norway have above-average $T_{\text {spring }}$ and $P_{\text {spring }}$ and half have below-average values. Also, winter air temperature preceding snowmelt droughts in Norway is indifferent (around $50 \%$ above and below; Fig. 5 - top left panel). Only winter precipitation shows a significant influence of decreasing discharge with decreasing precipitation and almost all snowmelt drought events (more than $90 \%$ ) were preceded by belowaverage winter precipitation (Fig. 5 - top right panel).
All glaciermelt drought events in Austria have belowaverage summer air temperature $(100 \%$ of all glaciermelt drought events; Fig. 6 - bottom left panel) and the severity of glaciermelt drought events increases with decreasing summer air temperature. Summer precipitation plays a role as well (Fig. 6 - bottom right panel). Half of the glaciermelt drought events had above-average summer precipitation, but these were events with relatively low deficit volumes. The more severe events (more than 5 times the catchment's average drought deficit) all had below-average $P_{\text {summer }}$. This points to a combined effect of a lack of glacier melt and a precipitation deficit. Meteorological conditions in the winter preceding glaciermelt drought events in Austria have less influence on droughts in summer. Interestingly, severe glaciermelt drought events have above-average winter precipitation (Fig. 6 - top right). Glaciermelt droughts in Austria also seem to have below-average winter air temperatures preceding the event ( $90 \%$ of all glaciermelt drought events; Fig. 6 top left). The physical process behind this pattern is unclear, but might be related to below-average summer air temperatures.

Glaciermelt droughts in Norway behave similarly in the sense that the influence of low summer air temperatures is dominant (more than $90 \%$ of all glaciermelt drought events had below-average $T_{\text {summer }}$; Fig. 7 - bottom left panel). However, the relationship of increasing drought severity with decreasing summer air temperature, as found for the Austrian catchments, is not so clear in Norway (Fig. 7). Summer precipitation (50\% below average and $50 \%$ above average), winter precipitation (also 50\%-50\%) and winter air temperature (35\% below average vs. $65 \%$ above average) do not seem to be causing factors for glaciermelt drought development in Norway. Similar scatter plots for simulated discharge are presented in Appendix A.

Table 3 quantifies the relationships observed in Figs. 47. Correlations above 0.5 have been found between $Q_{\text {spring }}$ and $T_{\text {spring }}$ for snowmelt droughts in Norway and between $Q_{\text {spring }}$ and $P_{\text {spring }}$ for snowmelt droughts in Austria. Glaciermelt droughts only showed high correlations in Austria, with correlations above 0.5 for $Q_{\text {summer }}$ and $T_{\text {summer }}$ and $Q_{\text {summer }}$ and $P_{\text {summer }}$. For snowmelt droughts, we expected a relationship with SWE or PlusZero, but neither Austria nor Norway showed a high correlation (Table 3). Correlations with drought deficit instead of discharge were also calculated, but did not result in any strong relationship.

When calculating the correlations per catchment independently we found interesting patterns. The correlation between $Q_{\text {summer }}$ and $T_{\text {summer }}$ seemed to increase with increasing glacier cover up to ca. $40 \%$ and levelling off afterwards (Fig. 8). The correlation between $Q_{\text {summer }}$ and $P_{\text {summer }}$ did not show any increase or decrease with increasing glacier cover, but it does confirm the difference between Norway and Austria, with Austrian catchments showing a larger effect of precipitation on glaciermelt droughts (Fig. 8). 

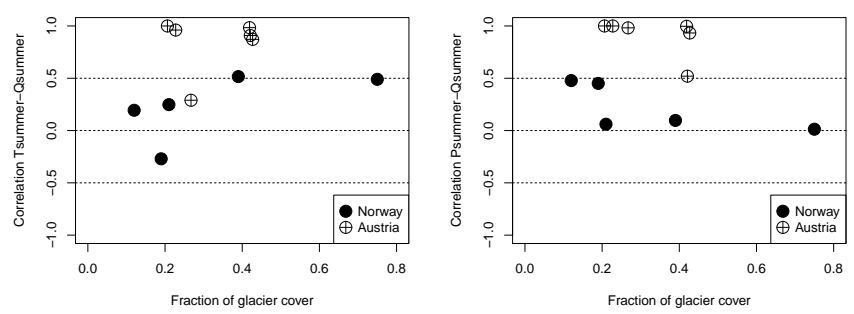

Figure 8. Correlation between $Q_{\text {summer }}$ and $T_{\text {summer }}$ and $P_{\text {summer }}$ for glaciermelt drought events in Austrian and Norwegian catchments in relation to fraction of glacier cover per catchment.

For snowmelt drought, we could not find a catchment characteristic that similarly explained the differences between catchments. Both correlations with $P$ and $T$ did not show any clear relationship with long-term average air temperature or snow cover (Fig. 9).

\section{Temperature-related drought types: socio-economic impacts}

Temperature-related drought types, like snowmelt drought and glaciermelt drought, but also rain-to-snow-season drought, cold snow season drought and warm snow season drought (see Table 1), are expected to have various socioeconomic impacts. In the regions used in the first part of this study, Norway and Austria, for example, the winter of 20132014 was very warm and dry, resulting in wildfires in Norway $^{1}$ and a lack of snow in ski resorts in Austria ${ }^{2}$. In Norway, the severe rain-to-snow-season drought in 2002-2003 can also be found in media sources impacting hydropower production and drinking water supply ${ }^{3}$. Except for a literature search in Van Loon and Van Lanen (2012), no drought impact analysis has ever focussed on temperature-related hydrological drought types. In this section we present a qualitative analysis of societal impacts of the existing HDTs rain-tosnow-season drought, cold snow season drought and warm snow season drought and the newly defined HDTs snowmelt drought and glaciermelt drought.

Descriptions of the socio-economic impacts of droughts, in the media or in government reports, are an important source of information. They can contribute to the understanding of the occurrence, severity and spatial distribution of temperature-related drought types. Here, we present the data, methods and results of our qualitative assessment of drought impacts. Unfortunately, the consistent collection, accessibility, and consolidation of these data sources is still limited. Therefore, not enough information was available to do this analysis for Norway and Austria and to link the impacts to the causing factors (Sect. 3), instead we decided to carry out

\footnotetext{
${ }^{1}$ robertscribbler.wordpress.com/2014/01/30

$2_{\text {www.planetski.eu/news/5896 }}$

${ }^{3}$ http://www.nve.no/en/Water/Hydrology/Flood-and-drought/
}
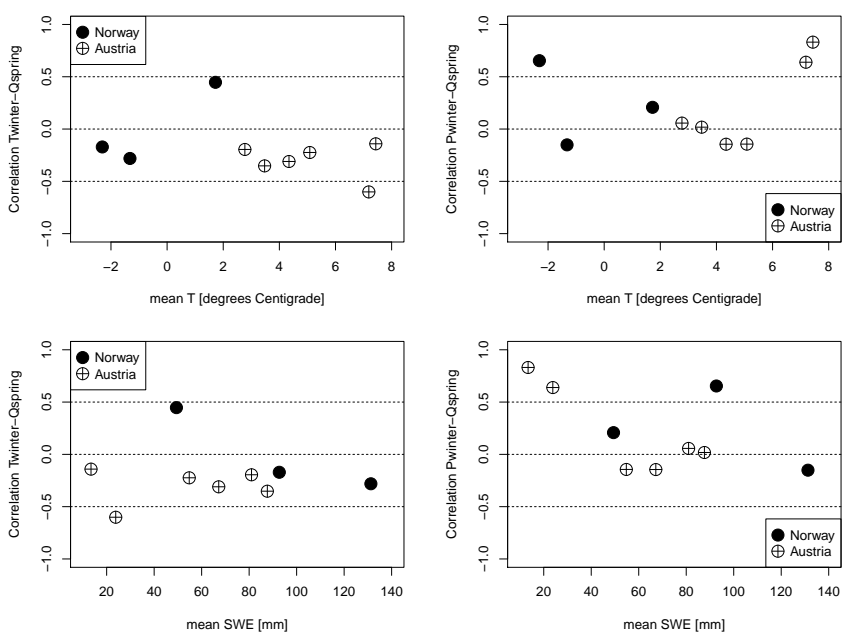

Figure 9. Correlation between $Q_{\text {spring }}$ and $T_{\text {winter }} / P_{\text {winter }}$ for snowmelt drought events in Austrian and Norwegian catchments in relation to catchment mean air temperature and snow cover.

a more extended survey on impacts of temperature-related droughts covering the entire Europe and the USA. From that general search, we defined regional events that we hoped to trace back in the hydrometeorological variables of our case study areas.

\subsection{Data and methodology}

Impacts of drought were not systematically collated before the last decade. In 2005 the National Drought Mitigation Center (NDMC, Lincoln, Nebraska) launched the Drought Impact Reporter (DIR), which was the USA's first comprehensive database of drought impacts (NDMC, 2014). Recently, the European Drought Observatory (EDO) has started to collect ongoing drought impacts in the European continent (JRC, 2014) through an automatic search of a wide range of sources. Parallel to this the DROUGHT-R\&SPI project has developed a European Drought Impact report Inventory (EDII), which is being filled with information on thousands of drought impacts that occurred in Europe, mainly over the last decades (Stahl et al., 2012). In this study we summarise drought impacts associated with temperature and snow conditions from: (i) historical archives, and (ii) the drought impact databases EDII and DIR.

\subsubsection{Historical archives}

Historians provide information on drought impacts beyond the instrumental record (e.g. earlier than mid 19th century when a more systematic monitoring of precipitation and river flow started). Different written sources are consulted and the information usually is hidden in the margins of the documents (e.g. Camuffo et al., 2010; Garnier, 2010a, b; Garcia de Cortazar-Atuari et al., 2010; Garnier et al., 2011). Diaries drafted by private persons (priests, middle-class per- 
Table 4. Severity classes and description for 16th-19th century drought events (Garnier, 2010a, 2014).

\begin{tabular}{ll}
\hline Index & Description \\
\hline 5 & Exceptional drought: no possible supply, shortage, sanitary problem, very high prices of wheat, forest fires \\
4 & Severe low-water mark: impossible navigation, layoff of wheat mills, search for new springs, forest fires, death of cattle \\
3 & General low waters (difficulties for navigation) and water reserves \\
2 & Local low waters of rivers, first effects on vegetation \\
1 & Absence of rainfall: rogations, evidence in texts \\
-1 & Insufficient qualitative and quantitative information, but the event is kept in the chronological reconstruction \\
\hline
\end{tabular}

Rogations = processions "pro pluvia" (literally "for the rain") organised by the Roman Catholic Church during drought events to avoid endangering the established order or the socio-economic balance.

sons, aristocrats), municipal chronicles and the archives of the Roman Catholic Church are particularly useful. Indications for drought events in the archival information are for instance: (i) phenology (state of the vegetation, fires), (ii) food prices on markets, and (iii) elements of social expression (scarcity, riots, religious processions "pro pluvia") that sometimes were combined with visual observations (water marks on bridges, ferry houses). Visual landmarks, for example, allowed to study the most severe winter droughts of the upper Rhine in the region of Basel (Pfister et al., 2006).

Up to the seventeenth century, droughts observed by historians are both "socio-economic drought" and "hydrological drought" (Fig. 1). Archives report low-water marks of rivers, death of fish, interruption of navigation, processions "pro pluvia", epidemics, etc. However, from 1750, historians can access instrumental data produced by the first scientific and meteorological European societies like the Royal Society of London, the Royal Society Medicine of Paris or the Societas Meteorologica Palatina of Mannheim (Germany). These instrumental data allow historians to include "meteorological drought" (Fig. 1).

In this study, we extracted information on historical drought events related to anomalies in air temperature or snow from French and English archives for the period 15001925. The total list included droughts beginning in winter or including winter. From this list we selected events that mention terms as snow, frost, freezing conditions, exceptionally cold or warm weather during the winter season. In England, five temperature-related events were selected from a British series of 50 droughts between 1539 and 2013. In France, four temperature-related events were selected from a French series counting 63 droughts between 1500 and 2014. The descriptive information of each event has been converted into a severity class (Table 4 ) and a HDT.

\subsubsection{Drought impact report database (EDII)}

A pan-European Drought Impact report Inventory (EDII) has been set up in the framework of the EU DROUGHTR\&SPI project (Fostering European Drought Research and Science-Policy Interfacing, www.eu-drought.org). An online database infrastructure with a standardised input interface has been created on the website of the European Drought Centre (www.geo.uio.no/edc). It allows submission of impact reports for the purpose of cross-disciplinary research on drought vulnerability and risk. The inventory contains data from the period 1904-2011 and it reveals a large variety of drought impacts and response measures across Europe (Stahl et al., 2012). Currently, EDII stores 4245 drought impact reports (state: 7 July 2014) and this number is still increasing. For this study, we queried the database for all years, all countries, all impact categories and all sources. Afterwards, we searched for the keywords snow, glacier, frost, winter and freeze and did a visual selection of drought events based on their description. We classified the selected drought events in HDTs.

\subsubsection{Drought Impact Reporter (DIR)}

The National Drought Mitigation Center has collated impacts from drought impacts that have occurred in the USA since 2004. In total 17195 impacts have been reported in the last ten years (state: 7 July 2014). Impact reports come, for instance, from media, Community Collaborative Rain, Hail and Snow network (CoCoRaHS), National Weather Service and private persons. Different categories have been distinguished, e.g. agriculture, business and industry, energy, fire, plants and wildlife, tourism and recreation, water supply and quality. For this study, we again used all impact categories and all sources. We queried the database for the keywords snow, glacier, frost, and winter. Results were so numerous that visual selection of events and application of the hydrological drought typology were not possible. Therefore, only a statistical analysis was performed on the DIR impacts.

\subsection{Results}

\subsubsection{Historical archives}

Historical archives in England and France covering the period 1500-1925 were studied to obtain information on drought connected to snow processes. Table 5 provides selected drought events. The estimated duration varies between 2 months and 1 year. The events are sometimes preceded by a dry summer or continue into the following summer, which 

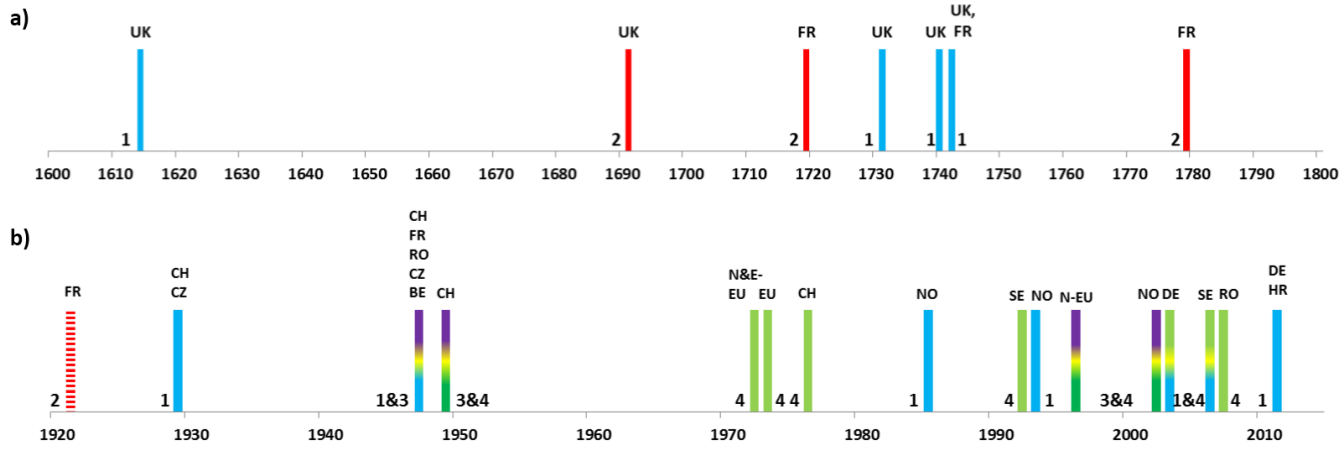

Figure 10. Selected drought events that are connected to winter temperature anomalies obtained from (a) historical archives, and (b) the EDII (except for the 1920 event, which is obtained from historical archives). (1) (blue): cold snow season drought, (2) (red): warm snow season drought; (3) (purple): rain-to-snow-season drought, and (4) (green): snowmelt drought. Abbreviations represent countries in Europe (EU).

results in a more severe drought event (e.g. the 1614 drought in Britain and the 1719 drought in Rhône-Alpes, Table 5). The severity class of all selected drought events ranges from 3 to 5 (Table 5), meaning "negative impacts on navigation and water resources due to below-normal water levels" up to "exceptionally dry conditions resulting in water shortage, forest fires, and food problems" (Table 4).

A bit more than half of the reported events are classified as cold snow season drought (Table 5 and Fig. 10a). The remaining events mentioned above-normal winter temperature and were therefore classified as warm snow season drought. All cold snow season droughts were of subtype $\mathrm{C}$ and all warm snow season droughts of subtype B, because winter air temperatures in France and England are normally around zero. Unfortunately, this type of archival information was not available for Austria and Norway (the case study areas used in Sect. 3) or for other regions with winter air temperatures far below zero, which could indicate historical occurrence of the other cold and warm snow season drought subtypes, rain-to-snow-season drought, snowmelt drought, and glaciermelt drought. Nevertheless, the impact reports for France and England show that negative impacts of drought due to anomalies in air temperature have already been documented for centuries.

\subsubsection{Drought impact databases}

The keywords snow, glacier, frost (freeze), and winter were mentioned slightly more than 300 times in the European Drought Impact report Inventory (EDII). The term "winter" appeared in about $90 \%$ of these selected impact reports. Clearly, not all drought impact reports with the term winter were related to winter processes, for example below-average winter wheat yield could be related to a rainfall deficit in spring. Therefore, we visually selected from these 300 entries the reports that were related to winter processes (anomalies in winter temperature, snow accumulation, etc.). The drought of 1972, for example, was "predominantly a winter and spring drought event. Beginning with low accumulated precipitation from the previous fall, the drought intensified due to low precipitation during the winter. The hydrological drought peak occurred March 1972 and was centred in Poland. According to Bradford (2000) drought in 1972 affected particularly the USSR with extreme low river levels". A more difficult one was, for example, the impact report of the 1947 drought, which occurred in a large part of Europe, amongst others in Romania, which states:

The winter of 1946/1947 was particularly severe, by the spring this led to flooding and this was then followed by one of the driest and hottest summers on record during 1947. Much of central Europe had then suffered lower than normal harvests for three years. In some parts of eastern Europe, such as north-eastern Romania, more than $90 \%$ of the population was suffering from hunger after crop failures. This led to food aid from the US and instigation of the Marshall Plan (Sheffield and Wood, 2011).

Here, a combination of a cold snow season drought and a classical rainfall deficit drought caused the described impacts. These impact reports were taken into account in this study.

The keyword "snow" turned up in about $5 \%$ of the entries of the EDII. For example, the 1949 drought in Switzerland is related to snow anomalies:

During the complete hydrological year 1948/1949 streamflows were exceptionally low in Switzerland, which led to a significant drop in hydropower production of about $12 \%$ to a year of normal (average) streamflow conditions. This reduction was a result of a summer drought, but also a consequence of unusually low snow resources from the winter period. Already in December 1948 a ban on electrical room heating was imposed, followed by further restrictions (e.g. regarding lighting) in consequence of the extremely dry conditions in Jan- 
Table 5. Selected drought events in England and France that are connected to anomalies in winter temperature, snow, and/or frost.

\begin{tabular}{|c|c|c|c|c|c|c|c|c|}
\hline Site & Year & Starting date & Ending date & Remark & $\begin{array}{l}\text { Relative } \\
\text { duration }\end{array}$ & $\begin{array}{l}\text { Severity } \\
\text { index }\end{array}$ & Source & Typology \\
\hline Britain & 1614 & January & August & $\begin{array}{l}\text { It began to snow and freeze on } 16 \text { January, and the frost continued unbroken, } \\
\text { with occasional snow, until } 7 \text { March, by which time the depth of snow was } \\
\text { greater than in any other year within "living memory". When the thaw came, } \\
\text { there was a great flood, but without rain, and the drought continued until } \\
20 \text { August. Great scarcity of hay and corn. }\end{array}$ & 240 days & 5 & $\begin{array}{l}\text { Annals of } \\
\text { Cambridge, } \\
\text { volume } 3\end{array}$ & $\begin{array}{l}\text { Cold snow season drought } \\
\text { - type C }\end{array}$ \\
\hline Britain & 1691 & & & $\begin{array}{l}\text { Rainfall were only } 72 \% \text { of normal, or less than } 3 / 4 \text {. Autumn was an extraor- } \\
\text { dinary dry and hot season, and winter was exceeding dry and calm; "no rain } \\
\text { for many months past". }\end{array}$ & 150 days & 3 & $\begin{array}{l}\text { Annals of } \\
\text { Cambridge, } \\
\text { volume } 3\end{array}$ & $\begin{array}{l}\text { Warm snow season drought } \\
\text {-type B }\end{array}$ \\
\hline Rhône-Alpes & 1719 & January & July & $\begin{array}{l}\text { The drought is preceded by very dry summer, } 1718 \text { and without rain. The } \\
\text { winter, } 1719 \text {, is very soft and dry (fewer than } 2 \text { frost days). The agricultural } \\
\text { consequences are important: no hay, the harvest of the wheat begins on } \\
12 \text { June, almost no vegetables in gardens. The Loire and the Rhône are very } \\
\text { low and the epidemics (bad quality of water) spread. }\end{array}$ & 1 year? & 5 & $\begin{array}{l}\text { Archives } \\
\text { municipales de } \\
\text { Lyon, BB } 292\end{array}$ & $\begin{array}{l}\text { Warm snow season drought } \\
\text { - type B }\end{array}$ \\
\hline Britain & 1731 & December & October & $\begin{array}{l}\text { It opened with a great frost and some snow in winter, but the summer was } \\
\text { hot, especially September, which was also exceptionally dry. }\end{array}$ & & & $\begin{array}{l}\text { Annals of } \\
\text { Cambridge, } \\
\text { volume } 3\end{array}$ & $\begin{array}{l}\text { Cold snow season drought } \\
\text { - type C }\end{array}$ \\
\hline Britain & 1740 & December 1739 & July 1740 & $\begin{array}{l}\text { The drought began, as often, with a frost. The Thames was frozen over in } \\
\text { December } 1739 \text {, and a famous frost fair was held on the river from Christ- } \\
\text { mas Day of that year until } 17 \text { February } 1740 \text {. A printing press was set up } \\
\text { on the ice, on which mementoes of the great frost were printed. The win- } \\
\text { ter, besides being exceptionally cold, was very dry; archives declare not } 3 \mathrm{~h} \\
\text { continued rain from the beginning of November until the following April } \\
\text { and the drought lasted with unabated severity until the end of July. }\end{array}$ & 240 days & 3 & $\begin{array}{l}\text { Annals of } \\
\text { Cambridge, } \\
\text { volume } 3\end{array}$ & $\begin{array}{l}\text { Cold snow season drought } \\
\text { - type C }\end{array}$ \\
\hline Britain & 1742 & February & December & $\begin{array}{l}\text { The greater part of January was mild and fairly rainy. February, March and } \\
\text { April were dry and cold, especially March, during which month both Ply- } \\
\text { mouth and Lyndon were practically rainless. December } 1742 \text { closed with } \\
3 \text { weeks of very severe frost without snow. The year as a whole had } 80 \% \text { of } \\
\text { the standard normal rainfall over England. }\end{array}$ & 330 days & 3 & $\begin{array}{l}\text { James Woodforde's } \\
\text { diary }\end{array}$ & $\begin{array}{l}\text { Cold snow season drought } \\
\text { - type C }\end{array}$ \\
\hline $\begin{array}{l}\text { Rhône and } \\
\text { Loire valleys }\end{array}$ & 1742 & January & April & $\begin{array}{l}\text { The drought lasts between January and April 1741, period in the course of } \\
\text { which it rains not at all. The north wind ("bise" in French) blows constantly } \\
\text { from January on } 15 \text { April. Grapes are very damaged in Beaujolais and in } \\
\text { the Monts du Lyonnais. }\end{array}$ & 120 days & 3 & $\begin{array}{l}\text { Archives } \\
\text { départementales } \\
\text { Rhône, } 5 \text { Mi } 345\end{array}$ & $\begin{array}{l}\text { Cold snow season drought } \\
\text { - type C }\end{array}$ \\
\hline Lyonnais & 1779 & Christmas 1778 & February 1779 & $\begin{array}{l}\text { December, January and February are very hot. There is neither snow nor } \\
\text { rain. The harvests are reduced (in particular potatoes) and destroyed by } \\
\text { cockchafers. }\end{array}$ & 60 days & 3 & $\begin{array}{l}\text { Journal de Claude } \\
\text { Bellod, p. } 91\end{array}$ & $\begin{array}{l}\text { Warm snow season drought } \\
\text { - type B }\end{array}$ \\
\hline France & 1921 & Autumn 1920 & July 1921 & $\begin{array}{l}\text { The hottest and the driest year in Paris since } 1873 \text {. It falls only } 270 \mathrm{~mm} \\
\text { (against } 625 \mathrm{~mm} \text { on average). The drought begins in autumn, } 1920 \text { and in- } \\
\text { creases in February (no rain drop on Beauce, the south of Champagne and } \\
\text { Jura). In Paris, June is the driest since } 1813 \text {. Between } 22 \text { May and } 11 \text { July, } \\
\text { only } 2 \mathrm{~mm} \text { falls on Paris. The drought is European: Holland, England and } \\
\text { Russia, which knows a famine. }\end{array}$ & 270 days & 4 & $\begin{array}{l}\text { Bulletin } \\
\text { municipal officiel } \\
\text { de Paris }\end{array}$ & $\begin{array}{l}\text { Warm snow season drought } \\
\text { - type B }\end{array}$ \\
\hline
\end{tabular}

uary and February. Those restrictions kept in force until the beginning of April (Schorer, 1992).

The visual selection of the 300 impact reports resulted in 30 reports that could be attributed to one of the temperaturerelated HDTs, representing 15 separate events (many drought events were reported more times in different countries). Figure 10b shows these selected drought events retrieved from the EDII that were related to temperature and snow. Reported impacts are for example strongly reduced tree growth and reduced crop yields due to cold spring, higher energy prices and energy use restrictions due to deficits in hydropower production, water use restrictions due to low flows, low reservoir levels and dry wells.

The drought events have different underlying processes and are classified as cold snow season drought, snowmelt drought, and rain-to-snow-season drought. The selected drought impacts show that these HDTs have occurred often in the last century. In $40 \%$ of the selected drought impacts a combination of HDTs occurred (Fig. 10). Especially, the combination of a snowmelt drought in spring and a rain-to-snow-season drought in summer and winter resulted in very severe socio-economic impacts. Also, a cold snow season drought followed by a snowmelt drought was reported to have a large effect on reservoir levels and, consequently, on drinking water and electricity production. Some temperature-related drought events occurred in a large region (e.g. the droughts in 1947, 1973 and 1996), but their impacts are diverse, partly because of the different physical circumstances depending on local air temperature and snow thresholds (even resulting in different HDTs in different parts), and partly because sectors are impacted differently in different regions because of socio-economic circumstances.

Additionally, we queried the US Drought Impact Report (DIR) with the same keywords as the EDII. The keywords snow, glacier, frost and winter were reported slightly more than 1300 times in the impact database coordinated by the National Drought Mitigation Center (NDMC, 2014). Each of these impacts was classified into one or more categories. Most temperature-related drought impacts were reported with the category "Agriculture", about $3.5 \%$ of all impacts in the DIR and $57 \%$ of the temperature-related impacts (Table 6). However, most of these impacts were again related to winter wheat and not always to a snow-related drought in winter. Other important categories are water supply and quality (mentioned in $27 \%$ of the impacts), plants and wildlife $(26 \%)$, and others (e.g. society and public health; $28 \%$ ). 
Table 6. Number of reported impacts for selected keywords and categories in the Drought Impact Reporter in the USA since 2004.

\begin{tabular}{|c|c|c|c|c|c|c|c|c|c|}
\hline \multirow[b]{2}{*}{ Keywords } & \multirow[b]{2}{*}{$\begin{array}{l}\text { No. of } \\
\text { impacts }\end{array}$} & \multicolumn{8}{|c|}{ Categories } \\
\hline & & Agriculture & $\begin{array}{r}\text { Business } \\
\text { and industry }\end{array}$ & Energy & $\begin{array}{r}\text { Plants and } \\
\text { fire }\end{array}$ & $\begin{array}{l}\text { Tourism } \\
\text { wildlife }\end{array}$ & $\begin{array}{l}\text { Water supply } \\
\text { and recreation }\end{array}$ & and quality & Others \\
\hline Snow & 272 & 98 & 39 & 8 & 53 & 80 & 75 & 89 & 100 \\
\hline Glacier & 7 & 3 & 0 & 0 & 3 & 0 & 0 & 0 & 4 \\
\hline Frost & 54 & 37 & 1 & 1 & 6 & 15 & 0 & 13 & 14 \\
\hline Winter & 979 & 609 & 39 & 12 & 121 & 250 & 63 & 249 & 243 \\
\hline
\end{tabular}

Most temperature-related impacts are reported by the media and the CoCoRaHS, but also many reports are from local farmers.

Many temperature-related drought impact reports in DIR are from the winter of 2013-2014, when it was extremely cold in large parts of the USA. These impacts relate to a cold snow season drought. In other parts of the country (e.g. California) the warm and dry winter resulted in a warm snow season drought with impact reports on wildfires, water use restrictions, closing of ski resorts ("Snowfall has not been so low at the 25 ski resorts in California since the 1971-1972 season."), low reservoir levels and irrigation problems. The seven impacts with the keyword "glacier" (Table 6) were all related to drought events in Glacier County and Glacier National Park. From the description it was unclear whether the mentioned drought impacts had any relation with air temperature, snow or glaciers.

In the DIR, some positive events can also be found, for example "Oregon Department of Transportation has saved money on snow removal" in January 2014 and a report of "less foundation damage in Sioux City, Iowa, due to little moisture in soil" in April 2014. ("Below normal precipitation in Sioux City this winter reduced the number of "frost heave" incidents this spring. Fluctuating freezing and thawing events can lead moisture to be drawn up to the soil surface when the ground finally thaws in the spring and can damage concrete basements.") In the EDII, only negative consequences of drought are included (Stahl et al., 2012).

\subsubsection{Linking qualitative impact assessment to quantitative causing factors}

Since no drought impact information was available for our case study catchments in Norway and Austria, a direct link between the causing factors and impacts of temperaturerelated droughts could not be established. However, drought impacts reported in the wider region might be related to drought events our case study areas. In this section, we analyse the causing factors of a number of drought events reported in the EDII.

Not many drought impacts are reported in the region of Austria (see Stahl et al., 2012). Both the 1975-76 snowmelt drought reported in Switzerland and the 2011 drought re- ported in Germany and Croatia (Fig. 10b) are not covered by our time series (see Sect. 3.2). In the region of Norway (Sweden/northern Europe), impacts of three snowmelt droughts and one rain-to-snow-season drought that fall within our time series have been reported in the EDII.

In Fig. 11 the anomalies in $Q, P$ and $T$ for all Norwegian catchments (eight catchments; Table 2) are shown per event. In 2002-2003, Norway was impacted by a rain-tosnow-season drought, which in some regions was combined with a snowmelt drought (Fig. 10). Reports in the EDII mention:

- "failing of the inflow" to reservoirs due to "lack of precipitation in summer and autumn 2002"

- "energy prices doubled in three months"

- "several water utilities had dry wells and had to drill deeper wells"

- "less than expected snow melting in spring", which is "main source of groundwater"

The anomalies of hydrometeorological variables show that $P$ was below average in summer (for most catchments) and autumn 2002 and winter 2002-2003 (Fig. 11 - 2003). Although $Q_{\text {summer }}$ was still above average for most catchments, $Q_{\text {autumn }}, Q_{\text {winter }}$ and $Q_{\text {spring }}$ were below average for the majority of the catchments.

The snowmelt drought in Northern Europe in 1972 is mainly described in the EDII in terms of low river flows in spring. March newspaper items mention that "Alesund and other areas in Norway were affected by water use restrictions because of water shortage in 1972". The $Q$-anomalies in our catchments in Norway do not clearly show these low flows (Fig. 11 - 1972), only in two western Norwegian catchments $Q_{\text {spring }}$ was below average. This is surprising because both $P_{\text {winter }}$ and $P_{\text {spring }}$ had wide-spread below-average values. It might be related to the wet antecedent conditions (high $\left.P_{\text {autumn }}\right)$ or above-average temperatures in winter and spring leading to early snowmelt.

The snowmelt drought in Sweden in 1992 was reported to have severe impacts on trees. The EDII reports mention "widespread dieback of spruce", "yellow discolouration", and "damaged trees", because "winter 1991/92 was very poor 

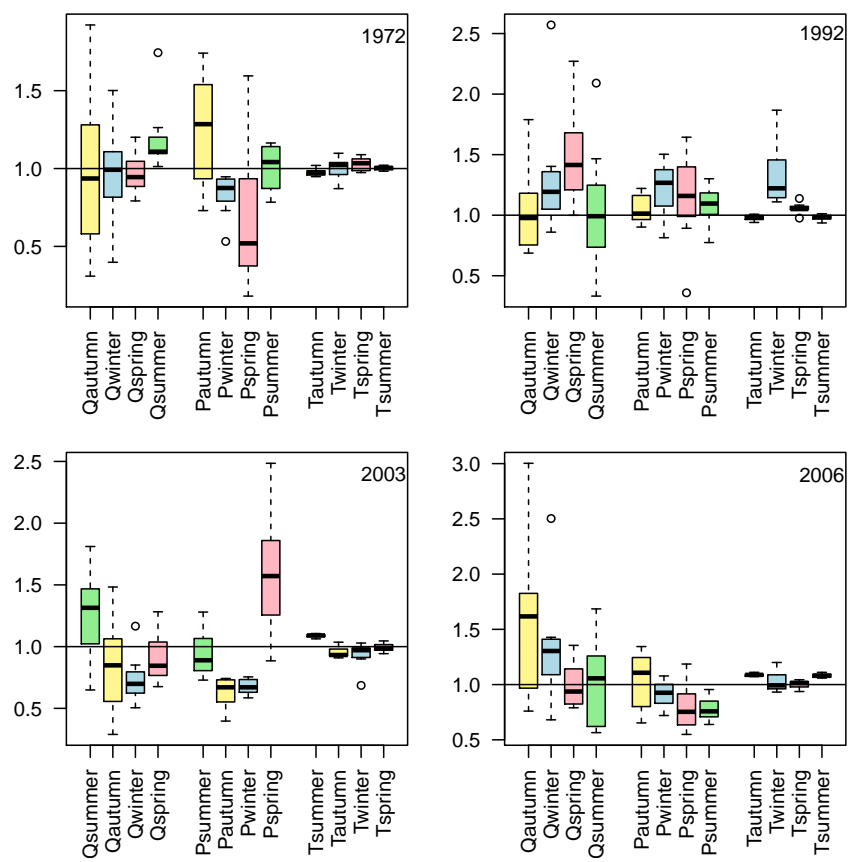

Figure 11. Anomalies of hydrometeorological variables for selected drought events in Norway (below $1=$ below average; above $1=$ above average). Boxplots represent values for all eight catchments in Norway.

in snow and water levels were low, then spring 1992 was extremely dry". The hydrometeorological variables of our catchments in Norway suggest that this situation did not occur in Norway (Fig. 11 - 1992). Spring discharge was actually above average, just like precipitation for the whole year (autumn, winter, spring, summer). $Q_{\text {summer }}$ was below average for many catchments, which is probably due to the abnormally high $T_{\text {winter }}$ leading to an early snowmelt peak and lower low flows in summer.

The snowmelt drought in Sweden in 2006 mainly impacted crop production, resulting in a record low harvest. Reported impacts in EDII are: "crop losses", "damage to crop quality or crop failure due to dieback", "premature ripening", and "drought-induced pest infestations or diseases". Additionally, low water levels were reported in "Nordic water reservoirs", which "pushed up the price of electricity significantly". This time Norway was probably also affected, at least some areas in Norway, as discharges in spring and summer were below average for many catchments (Fig. 11 -2006). This was probably related to below-average $P_{\text {winter }}$, $P_{\text {spring }}$ and $P_{\text {summer }}$, and possibly also to above-average temperatures.

\section{Discussion}

\subsection{Hypothesis 1: for each region, the occurrence and severity of the new HDTs can be related to meteorological causing factors in specific seasons}

In the quantitative analysis of causing factors of temperaturerelated droughts in Norway and Austria (Sect. 3), we found patterns in scatter plots of discharge vs. meteorological variables per region, but these patterns were not confirmed by the statistical analysis. A reason for that can be that severe and minor droughts are equally taken into account in the statistical analysis, while in the scatter plots the eye focuses on the more severe drought events. In Ploum and Van Loon (2014), significant statistical relationships were found when selecting the eight most severe drought events in glacierised catchments, with $T_{\text {summer }}$ being the most important explaining variable for $Q_{\text {summer }}$ and glaciermelt drought deficit.

Another reason can be that differences between catchments are too large to cluster the catchments and derive general relationships per region. Ploum and Van Loon (2014) found, for example, that in Gailtal (Fig. 3 and Table 2) droughts in the snowmelt period were related to $P$ and $T$ in spring, while in Mühlviertel (Fig. 3 and Table 2) winter conditions (snow accumulation and occasional melt due to high $T$ in winter) had more influence. This shows that the interaction between meteorological variables in different seasons is complex and can hardly be generalised. Therefore, processes underlying drought types should ideally be studied per (small) catchment. The disadvantage of that is that droughts do not occur regularly and time series are often too short to detect enough drought events for statistical analysis. In this study, we performed a first order statistical analysis. More elaborated analyses of the causing factors of drought types in different regions and climates, might be an interesting next step.

Also, uncertainties in data can be (part of) the reason for limited statistical relationships. We used well-established data sets of catchments in Austria (Parajka and Blöschl, 2008; Merz et al., 2011; Haslinger et al., 2014) and Norway (Mohr and Tveito, 2008; Engelhadt et al., 2012; Fleig et al., 2013) that were thoroughly quality-checked and used in other scientific studies. However, measurement errors, uncertainties in the estimation of gridded data from station data, and issues of representativity can still occur, especially in mountainous catchments. Furthermore, in drought analysis and classification, subjective choices cannot be avoided. For applying the hydrological drought typology, unfortunately no automatic procedure is available (yet).

Regimes of snowmelt and glaciermelt are different in regions around the world and even differ per catchment and within catchment, because altitude influences the air temperature regime and therefore snow accumulation (Marsh and Woo, 1981). Weingartner et al. (2013) showed this variability by presenting a diagram with the effects of seasonality 
in precipitation and increasing snow cover on the discharge regime. In this research we only compared driving processes for snowmelt drought and glaciermelt drought under Alpine and Scandinavian conditions. For Alpine basins, our results correspond to the conclusions in Collins (1987) and Chen and Ohmura (1990), where annual discharge showed a clear year-to-year variation in relation to summer air temperature, and this relation was stronger in basins with a higher percentage glacier cover. Also, the larger spread in the relationship between summer air temperature and discharge above $30 \%$ ice cover found by Collins and Taylor (1990) for Alpine basins seems to correspond to the levelling off at ca. $40 \%$ in Fig. 8. For Norway, the importance of both winter precipitation and summer temperature for glacier mass balance and frontal advance is mentioned by e.g. Nesje (2005). Engelhardt et al. (2014) found that for a number of glacierised catchments in Norway, strong correlations with annual discharge changed from annual and winter precipitation for the most maritime glacier to summer air temperature for the most continental glacier.

The results of this study are too specific to be directly transferable to other regions with cold climates. For example, in part of the Himalayas, summer precipitation is more important than summer air temperature in determining summer discharge, because of the summer monsoon (Thayyen and Gergan, 2010). In this region glaciermelt droughts are probably very rare as discharge is hardly affected by summer air temperature. Almost all summer droughts in this area are probably rainfall deficit droughts. Spring discharge in the western Himalayas is mainly explained by winter precipitation (Pal et al., 2013), so snowmelt droughts in western Himalaya might have similar causing factors as snowmelt droughts in Norway. Snowmelt contributions to discharge differ, however, widely over the Himalayas: from up to $50 \%$ in the far western catchments, $25 \%$ in far eastern catchments, and less than $20 \%$ elsewhere (Bookhagen and Burbank, 2010).

Glacierised catchments in North America often show behaviour comparable to glacierised catchments in Europe. For example, Naz et al. (2014) found that for the Bow catchment in Canada, glaciermelt contribution to summer discharge is between $15 \%$ in cold years and $47 \%$ in warm and dry years. In the USA, Hall et al. (2012) found a strong relationship between spring discharge and snow covered area in winter.

In tropical regions with glaciers, such as in the tropical Andes, relationships between meteorological conditions and droughts are different than those in the regions described above. Due to year-round constant air temperatures there is no seasonality in glaciermelt (e.g. Juen et al., 2007). Precipitation will therefore have a larger effect on interannual variation in discharge. The opposite is the case for Antarctica with $100 \%$ glacier cover and a strong relationship with air temperature. For example, Doran et al. (2008) found up to 6000-fold increase in annual streamflow in a warm year compared to a cold year. For each of these regions, simi- lar analyses as in this paper can be performed to investigate the occurrence and causing factors of snowmelt droughts and glaciermelt droughts.

In scientific literature, no studies were found that focus specifically on the causing factors of a lack of snowmelt or glaciermelt. The opposite, however, is investigated often: snowmelt floods, for example the Pacific Northwest flood of 1996 (Marks et al., 1998), and record glaciermelt in warm summers, for example in 2003 in Europe (Paul et al., 2005; Koboltschnig et al., 2009).

In this study we assumed no major trends in hydrometeorological variables. That assumption does not completely hold. We noticed that in some catchments snowmelt drought events were clustered in the end of the period. Expected increasing air temperatures in the future will probably lead to more snowmelt droughts and less glaciermelt droughts. Climate change is also expected to change the relative influence of air temperature and precipitation in different seasons (Barnett et al., 2005; Stewart, 2009) and, consequently, the governing processes underlying drought types. An interesting follow up to this research would be an investigation of changes in the distribution over drought types and changes in causing factors per drought type over time. As was also mentioned before in Van Loon and Van Lanen (2012), the effects of climate change on HDTs is distinctly different between regions with winter air temperatures around zero and regions with winter air temperatures far below zero.

Knowledge of the causing factors of drought in spring and summer in snow-influenced and glacier-influenced basins can be useful for drought forecasting. For example, in catchments where winter conditions are dominant for spring/summer drought development, prediction of winter conditions is crucial. Recent developments in making winter meteorological predictions more accurate (Scaife et al., 2014) are also promising for multi-seasonal drought forecasting. However, more research is needed before this is possible.

\subsection{Hypothesis 2: HDTs in cold climates have had socio-economic impacts in the recent and distant past}

The temperature-related drought types regularly led to socioeconomic impacts as the (mostly qualitative) analysis of drought impacts in Europe and the USA (Sect. 4) showed. Unfortunately, the integration between the analysis of causing factors and impacts for specific case study areas was limited (Sect. 4.2.3), mainly because the data sources are not complete, not in time nor in space. For this study, historical archives were, for example, only available from France and the UK. The EDII is Europe-wide, but does have a bias towards certain countries (e.g. Germany) (Stahl et al., 2012). Furthermore, both EDII and DIR are recent databases and continue to be filled. Currently, entries are biased towards later years. This type of information also suffers from language issues, at least in Europe compared to the USA. There- 
fore, a quality check on drought impact reporting or drought impact media searches is always needed, which makes collecting these data very time-consuming.

There are some initiatives for extending drought impact databases. The European Drought Observatory (EDO) has started to collect ongoing drought impacts (JRC, 2014) and the UCL Global Drought Monitor is in process of adding a Drought Impact Reporter. These initiatives provide opportunities to repeat the analysis of impacts of temperaturerelated droughts with more information. Because drought is an extreme event with a low frequency of occurrence it is important not only to look at current drought impacts, but also to put some effort in collecting historical impact information, both from the recent (last century) and distant past.

From the impact reports, we could see that most severe impacts occur after a combination of a number of (different) drought types. For example, a cold snow season drought in winter and spring followed by a classical rainfall deficit drought in summer is a devastating combination for crop production. The combination of the rain-to-snowseason drought and a snowmelt drought causes record low water levels in rivers, lakes and reservoirs. This makes it important not only to look at the frequency of occurrence of HDTs, but also at their timing and sequence.

Both in the historical analysis and in the impact databases no glaciermelt droughts were found. There can be several reasons for that: (i) glaciermelt droughts do not occur, (ii) glaciermelt droughts do not have socio-economic impacts, (iii) glaciermelt drought impacts are not reported in EDII and DIR, because there is a lack of entries from glacierised regions, and in developed countries (like Switzerland) impacts are compensated by large storage reservoirs, (iv) glaciermelt drought impacts are not reported because a lack of glaciermelt is not called a drought in public discourse and newspapers. We did not find glaciermelt droughts in the historical archives either, but, as mentioned before, the historical archives were not investigated in countries with severe winters, continuous snow accumulation, and glaciers (e.g. the Alpine region or Scandinavia).

The documented impacts in EDII cluster towards the end of the investigated period (Fig. 10). In contrast to our conclusion from the quantitative analysis (see above), this is likely not related to effects of climate change, but mainly a reporting and documentation bias. The effect of climate change on drought impacts can only be investigated if numbers of drought impact reports in the databases are significantly higher.

\section{Summary and conclusions}

In this paper, we investigated hydrological droughts related to air temperature anomalies and anomalies in snowmelt and glaciermelt. We added two new hydrological drought types to the hydrological drought typology developed in
Van Loon and Van Lanen (2012). A snowmelt drought is a deficiency in the snowmelt discharge peak in spring in snowinfluenced basins and a glaciermelt drought is a deficiency in the glaciermelt discharge peak in summer in glacierised basins.

From a detailed analysis of meteorological conditions related to snowmelt droughts and glaciermelt droughts in 11 snow-influenced and 12 glacierised catchments in Austria and Norway, we found that possible causing factors are different in Austria and Norway. In Austria, snowmelt droughts are related to warm and dry winters, but spring conditions also seem to have an effect. In Norway, winter precipitation is the dominant factor in explaining snowmelt droughts. All glaciermelt drought events in Austria and almost all in Norway had below-average summer air temperature. In Austria, below-average summer precipitation was additionally important for the most severe drought events, whereas it did not play a role in Norway. Only the effect of spring precipitation on snowmelt drought and summer air temperature and precipitation on glaciermelt drought in Austria could be confirmed with statistical analysis. The high correlation between spring air temperature and discharge in snowmelt droughts in Norway contradicted the results from visual inspection of scatter plots for that region.

Our hypothesis that for each region occurrence and severity of the new hydrological drought types can be related to meteorological causing factors in specific seasons was partly confirmed and partly rejected. We did find differences in occurrence and severity for drought types in Austria and Norway and could visually relate them to meteorological conditions in the seasons preceding and at the time of the drought event, but these relationships were not always confirmed statistically. In other snow or glacier-influenced regions around the world the balance between air temperature and precipitation in winter, spring and summer can be different resulting in different (combinations of) causing factors for snowmelt droughts and glaciermelt droughts. This can be investigated using the type of analysis presented in this paper. This is especially interesting in the light of the effects of climate change.

In the last part of this paper we investigated whether temperature-related drought types were of any relevance to socio-economic factors using both historical archives and recent drought impact databases. Many impacts were found for various temperature-related drought types. Cold and warm snow season droughts were abundant in historical archives of the UK and France in the period 1600-1800. Cold snow season droughts, snowmelt droughts and a number of combined temperature-related droughts were found in the European Drought Impact report Inventory (EDII) in the period 1925-2011. The keywords snow, glacier, frost (freeze), and winter were mentioned over 300 times in the EDII and over 1300 times in the US Drought Impact Reporter (DIR). In the DIR the dominant categories were Agriculture, Water supply and quality, and Plants and wildlife. The EDII re- 
ports were visually selected and finally represent 15 distinct drought events that mainly impacted hydropower production and crop yield in various countries in Europe. Analysis of the hydrometeorological anomalies of selected events in the region of our case study catchments in Norway showed that especially the 2002-2003 and 2006 drought events could be reproduced.
Our second hypothesis, that hydrological drought types in cold climates have had socio-economic impacts in the recent and distant past, was mostly confirmed. Only for glaciermelt droughts were no related socio-economic impacts found. This is likely to be caused by a reporting bias (lack of glacierised areas in databases, other terms used to describe glacier melt deficiency), so hopefully continuing efforts to improve and extend drought impact databases and historical drought research will also provide information on the socio-economic impacts of glaciermelt droughts. 

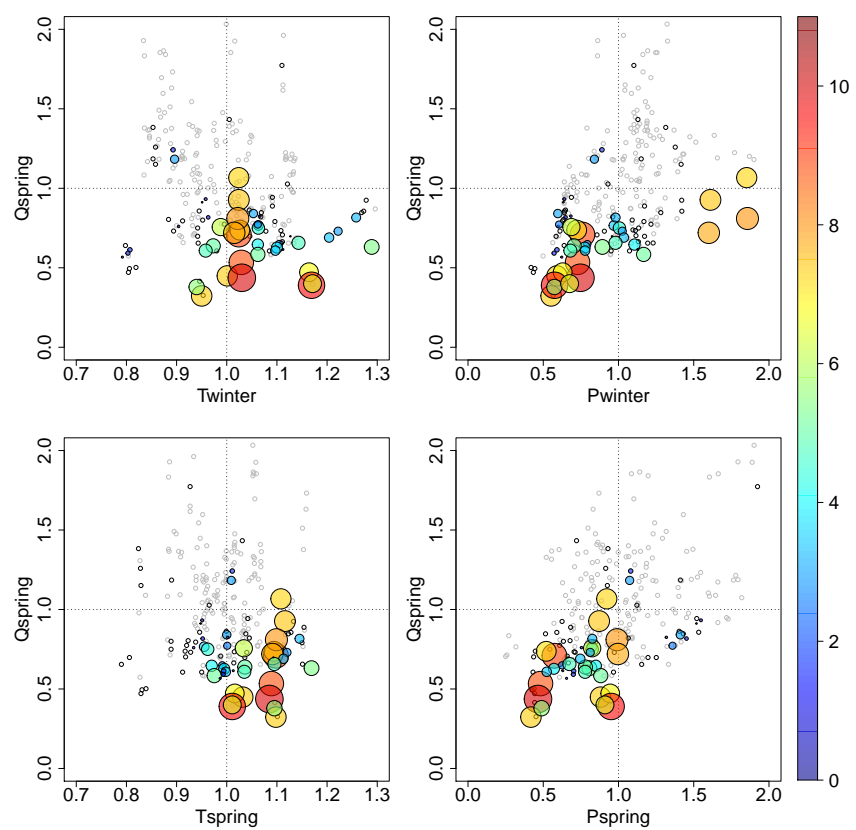

Figure A1. Snowmelt drought events in Austrian catchments based on simulated discharge: standardised spring discharge $\left(Q_{\text {spring }}\right)$ (-) against standardised causing factors $\left(T_{\text {winter }}, P_{\text {winter }}, T_{\text {spring }}\right.$, $P_{\text {spring }}$ ) (-). Below $1=$ below average; above $1=$ above average. Grey circles: all years; black circles: all drought years; coloured circles: snowmelt drought years (size and colour of dots are dependent on standardised drought deficit (-); scale on the right side of the figure). Note: selection of (snowmelt) drought years and size and colour of dots is based on observed discharge.

\section{Appendix A: Results based on simulated discharge}

The analyses in Sect. 3.4 are based on observed discharge. In this appendix they are repeated with simulated discharge, which allows for an evaluation of model performance in terms of anomalies. The advantage of using simulated instead of observed discharge is that there are no gaps, so all years are used for all catchments. The disadvantage can be that some processes are not well represented in the models. Both HBV versions did not include glaciers (Sect. 3.2).

In snow-dominated catchments, differences between anomalies in observed and simulated discharge are minor (Figs. A1 and A2 vs. Figs. 4 and 5). For Austria, some snowmelt drought years did not have strong anomalies in discharge; points were closer to the average line $\left(Q_{\text {spring }}=1\right)$. For Norway, only scatter is slightly less in simulated compared to observed discharge. In both areas, relationships between variables do not seem to be affected.
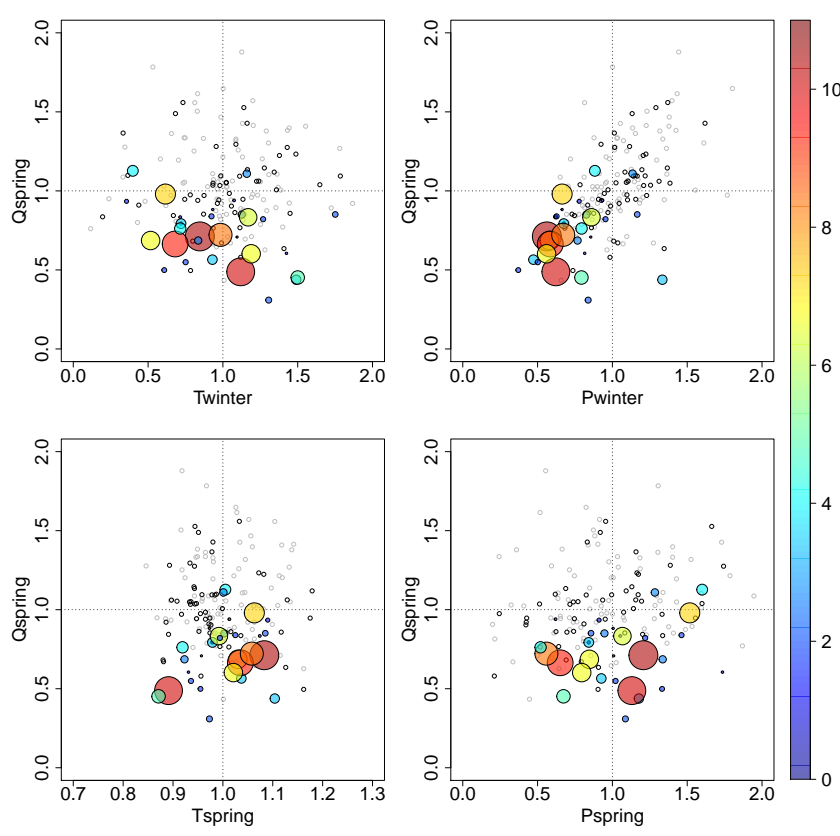

Figure A2. Snowmelt drought events in Norwegian catchments based on simulated discharge: standardised spring discharge ( $Q_{\text {spring }}$ ) (-) against standardised causing factors ( $T_{\text {winter }}, P_{\text {winter }}$, $\left.T_{\text {spring }}, P_{\text {spring }}\right)(-)$. Below $1=$ below average; above $1=$ above average. Grey circles: all years; black circles: all drought years; coloured circles: snowmelt drought years (size and colour of dots are dependent on standardised drought deficit (-); scale on the right side of the figure). Note: selection of (snowmelt) drought years and size and colour of dots is based on observed discharge.

In glacier-dominated catchments, however, differences are quite substantial (Figs. A3 and A4 vs. Figs. 6, 7). Especially for Norway, the simulations show much less variability in flow. For Austria, the relationship between simulated $Q$ and $T$ is less pronounced than for observed $Q$ and the relationship between simulated $Q$ and $P$ is more pronounced than for observed $Q$ (also, $P_{\text {winter }}$ seems to have a stronger influence on $Q_{\text {summer }}$ ).

The correlations between the hydrometeorological variables mostly have a similar pattern (Table A1 vs. Table 3). It is striking to see that in Norway no correlations above 0.5 appear when using simulated $Q$. Additionally, correlation with snow simulations seems to be different, i.e. higher with $Q_{\text {spring }}$ in Austria and lower with $Q_{\text {summer }}$ in Austria.

The conclusion from this analysis on simulated $Q$ is that, in general, droughts are simulated well, except for a decrease in flow variability in Norwegian glacier-dominated catchments. Furthermore, the relation between snow accumulation, melt and discharge is probably more complex in reality compared to the model. 

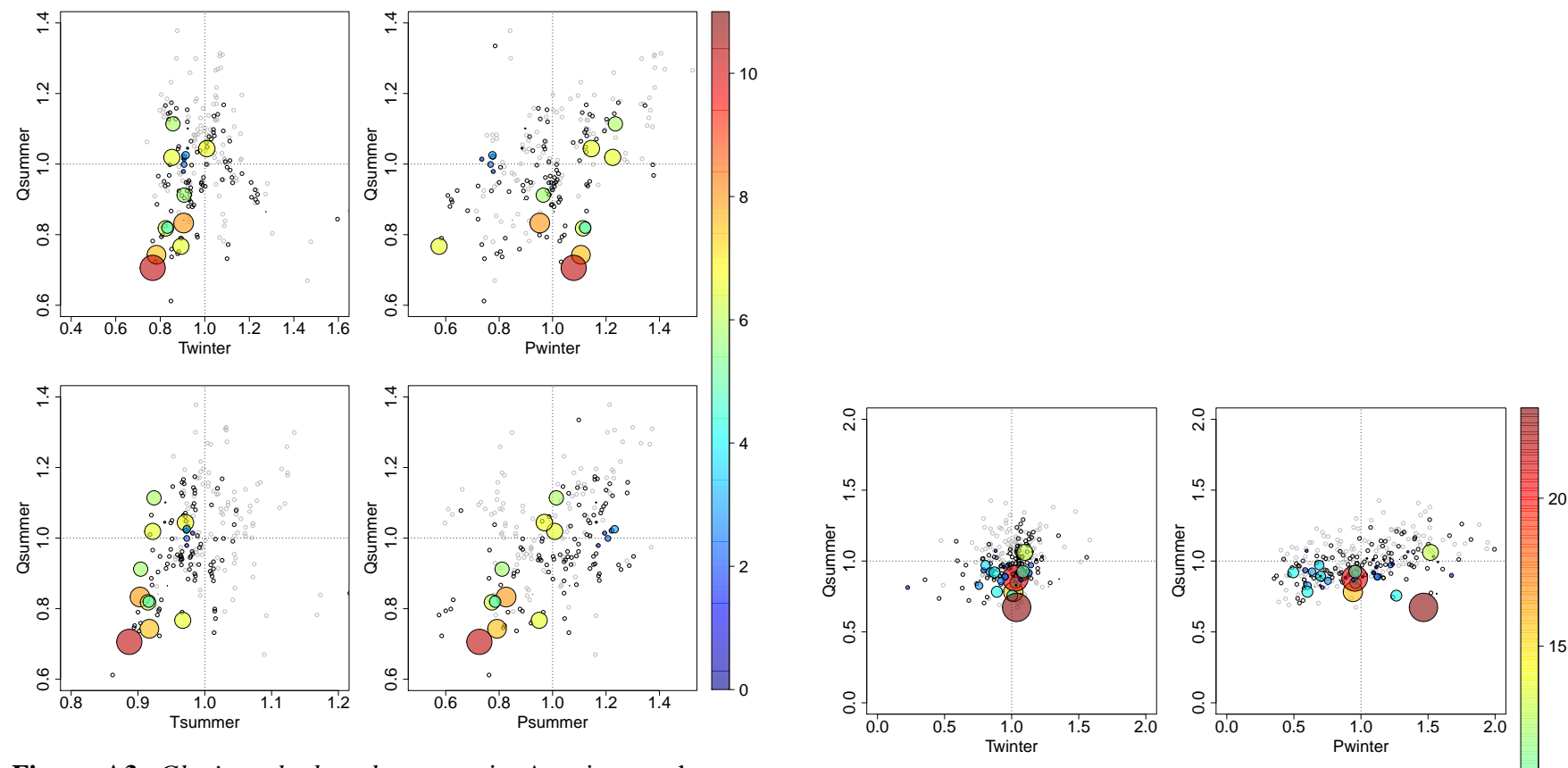

Figure A3. Glaciermelt drought events in Austrian catchments based on simulated discharge: standardised summer discharge ( $Q_{\text {summer }}$ ) (-) against standardised causing factors $\left(T_{\text {winter }}, P_{\text {winter }}\right.$, $\left.T_{\text {summer }}, P_{\text {summer }}\right)(-)$. Below $1=$ below average; above $1=$ above average. Grey circles: all years; black circles: all drought years; coloured circles: glaciermelt drought years (size and colour of dots are dependent on standardised drought deficit (-); scale on the right side of the figure). Note: selection of (snowmelt) drought years and size and colour of dots is based on observed discharge.

Table A1. Correlation between simulated $Q_{\text {spring }}$ and possible related meteorological factors for snowmelt drought and between simulated $Q_{\text {summer }}$ and possible related meteorological factors for glaciermelt drought. Correlations above 0.5 are indicated in bold.

\begin{tabular}{lllll}
\hline & \multicolumn{4}{c}{ Hydrological variables } \\
\cline { 2 - 5 } $\begin{array}{l}\text { Meteorological } \\
\text { variable }\end{array}$ & $\begin{array}{c}Q_{\text {spring }} \\
\text { Austria }\end{array}$ & $\begin{array}{c}Q_{\text {spring }} \\
\text { Norway }\end{array}$ & $\begin{array}{l}Q_{\text {summer }} \\
\text { Austria }\end{array}$ & $\begin{array}{c}Q_{\text {summer }} \\
\text { Norway }\end{array}$ \\
\hline$T_{\text {winter }}$ & -0.17 & -0.34 & 0.22 & 0.21 \\
$P_{\text {winter }}$ & 0.38 & 0.24 & -0.04 & 0.17 \\
SWE $_{\text {winter }}$ & 0.27 & 0.02 & & \\
PlusZero & 0.24 & -0.09 & & \\
$T_{\text {spring }}$ & -0.1 & 0.33 & & \\
$P_{\text {spring }}$ & $\mathbf{0 . 5 5}$ & 0.14 & & \\
$T_{\text {summer }}$ & & & $\mathbf{0 . 5 2}$ & 0.42 \\
$P_{\text {summer }}$ & & & $\mathbf{0 . 7 7}$ & 0.07 \\
\hline
\end{tabular}
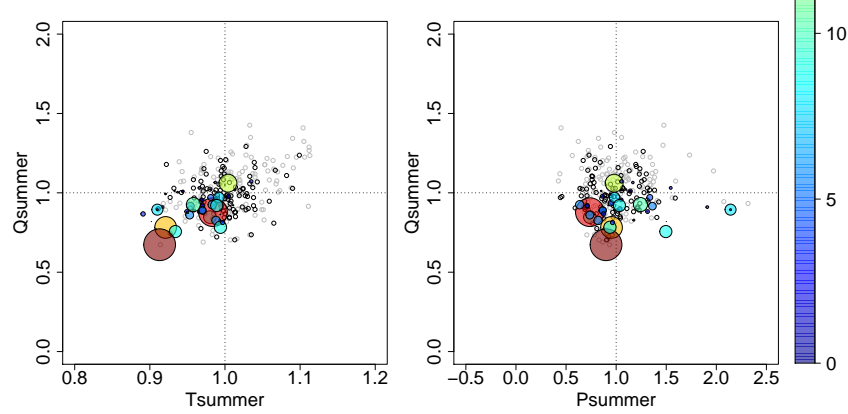

Figure A4. Glaciermelt drought events in Norwegian catchments based on simulated discharge: standardised summer discharge ( $\left.Q_{\text {summer }}\right)(-)$ against standardised causing factors $\left(T_{\text {winter }}, P_{\text {winter }}\right.$, $\left.T_{\text {summer }}, P_{\text {summer }}\right)(-)$. Below $1=$ below average; above $1=$ above average. Grey circles: all years; black circles: all drought years; coloured circles: glaciermelt drought years (size and colour of dots is dependent on standardised drought deficit (-); scale on the right side of the figure). Note: selection of (snowmelt) drought years and size and colour of dots is based on observed discharge. 
Acknowledgements. This research was undertaken as part of the European Union (FP7) funded DROUGHT-R\&SPI (contract no. 282769) project. It is part of the programme of the Wageningen Institute for Environment and Climate Research (WIMEK-SENSE) and it supports the work of the UNESCO-IHP VIII FRIEND programme. We thank Lena Tallaksen (University of Oslo) for suggesting the topic of this study and all EDII and DIR contributors for compiling the Drought Impact report databases. We are indebted to Klaus Hasslinger (ZAMF) for providing hydrometeorological data of the Austrian study catchments and to Hege Hisdal, Gusong Ruan and Ingjerd Haddeland (NVE) for providing hydrometeorological data of the Norwegian study catchments.

Edited by: H. Cloke

\section{References}

Barnett, T. P., Adam, J. C., and Lettenmaier, D. P.: Potential impacts of a warming climate on water availability in snow-dominated regions, Nature, 438, 303-309, doi:10.1038/nature04141, 2005.

Beldring, S., Engeland, K., Roald, L. A., Sælthun, N. R., and Voks $\varnothing$, A.: Estimation of parameters in a distributed precipitationrunoff model for Norway, Hydrol. Earth Syst. Sci., 7, 304-316, doi:10.5194/hess-7-304-2003, 2003.

Bergström, S.: The HBV Model, Water Resources Publications, Colorado, USA, 443-476, 1995.

Beyene, B., Van Loon, A., Van Lanen, H., and Torfs, P.: Investigation of variable threshold level approaches for hydrological drought identification, Hydrol. Earth Syst. Sci. Discuss., 11, 12765-12797, doi:10.5194/hessd-11-12765-2014, 2014.

Bookhagen, B. and Burbank, D. W.: Toward a complete Himalayan hydrological budget: spatiotemporal distribution of snowmelt and rainfall and their impact on river discharge, J. Geophys. Res.Earth, 115, F03019, doi:10.1029/2009JF001426, 2010.

Bradford, R. B.: Drought events in Europe, in: Drought and Drought Mitigation in Europe, Advances in Natural and Technological Hazards Research, Vol. 14, Kluwer Academic Publishers, Dordrecht, the Netherlands, 7-20, 2000.

Camuffo, D., Bertolin, C., Barriendos, M., Dominguez-Castro, F., Cocheo, C., Enzi, S., Sghedoni, M., della Valle, A., Garnier, E., Alcoforado, M.-J., Xoplaki, E., Luterbacher, J., Diodato, N., Maugeri, M., Nunes, M. F., and Rodriguez, R.: 500-years temperature reconstruction in the Mediterranean Basin by means of documentary data and instrumental observations, Clim. Change, 101, 169-199, 2010.

Chen, J. and Ohmura, A.: On the influence of Alpine glaciers on runoff, Hydrology in Mountainous Regions, IAHS-AISH P., 193, 117-125, 1990.

Collins, D. N.: Climatic fluctuations and runoff from glacierised Alpine basins, The influence of climate change and climatic variability on the hydrologic regime and water resources, IAHSAISH P., 168, 77-89, 1987.

Collins, D. N. and Taylor, D.: Variability of runoff from partiallyglacierised Alpine basins, Hydrology in mountainous regions, IAHS-AISH P., 193, 365-372, 1990.

Doran, P. T., McKay, C. P., Fountain, A. G., Nylen, T., McKnight, D. M., Jaros, C., and Barrett, J. E.: Hydrologic response to extreme warm and cold summers in the McMurdo
Dry Valleys, East Antarctica, Antarct. Sci., 20, 499-509, doi:10.1017/S0954102008001272, 2008.

Engelhadt, M., Schuler, T., and Andreassen, L.: Evaluation of gridded precipitation for Norway using glacier mass-balance measurements, Geogr. Annal.: Series A, Physical Geography, 94, 501-509, doi:10.1111/j.1468-0459.2012.00473.x, 2012.

Engelhardt, M., Schuler, T. V., and Andreassen, L. M.: Contribution of snow and glacier melt to discharge for highly glacierised catchments in Norway, Hydrol. Earth Syst. Sci., 18, 511-523, doi:10.5194/hess-18-511-2014, 2014.

Feyen, L. and Dankers, R.: Impact of global warming on streamflow drought in Europe, J. Geophys. Res., 114, D17116, doi:10.1029/2008jd011438, 2009.

Fleig, A., Andreassen, L., Barfod, E., Haga, J., Haugen, L., Hisdal, H., Melvold, K., and Saloranta, T.: Norwegian Hydrological Reference Dataset for Climate Change Studies, Report 2-2013, NVE, Oslo, Norway, 2013.

Fleig, A. K., Tallaksen, L. M., Hisdal, H., and Demuth, S.: A global evaluation of streamflow drought characteristics, Hydrol. Earth Syst. Sci., 10, 535-552, doi:10.5194/hess-10-535-2006, 2006.

Gaál, L., Szolgay, J., Kohnová, S., Parajka, J., Merz, R., Viglione, A., and Blöschl, G.: Flood timescales: understanding the interplay of climate and catchment processes through comparative hydrology, Water Resour. Res., 48, W04511, doi:10.1029/2011WR011509, 2012.

Garcia de Cortazar-Atuari, I., Daux, V., Garnier, E., Yiou, P., Viovy, N., Seguin, B., Boursiquot, J., Parker, A., Van Leeuwen, C., and Chuine, I.: Climate reconstructions from grape harvest dates: methodology and uncertainties, Holocene, 20, 599-608, 2010.

Garnier, E.: Climat et Histoire, XVIe-XIXe siècles, Numéro Thématique 57-3, Revue d'Histoire Moderne et Contemporaine, Société d'histoire moderne et contemporaine, éditions Belin, Paris, France, 2010a.

Garnier, E.: Bassesses extraordinaires et grandes chaleurs. 500 ans de sécheresses et de chaleurs en france et dans les pays limitrophes (Exceptionnal Meanness Water and Hot Weather. 500 years of drought and heat wave in France and neighboring countries), Houille Blanche, 4, 26-42, 2010b.

Garnier, E.: Strengthened resilience from historic experience, European societies confronted with hydrometeors in the sixteenth to twentieth century, in: Hydrometeorological Hazards: Interfacing Science and Policy, edited by: Quevauviller, P., Wiley \& Sons, Ltd Published, 3-25, 2014.

Garnier, E., Daux, V., Yiou, P., and Garcia de Cortazar, I.: Grapevine harvest dates in Besançon between 1525 and 1847: social outcome or climatic evidence?, Clim. Change, 104, 703-727, 2011.

Hall, D. K., Foster, J. L., DiGirolamo, N. E., and Riggs, G. A.: Snow cover, snowmelt timing and stream power in the Wind River Range, Wyoming, Geomorphology, 137, 87-93, doi:10.1016/j.geomorph.2010.11.011, 2012.

Haslinger, K., Koffler, D., Schöner, W., and Laaha, G.: Exploring the link between meteorological drought and streamflow: effects of climate-catchment interaction, Water Resour. Res., 50, 24682487, doi:10.1002/2013WR015051, 2014.

Hisdal, H., Tallaksen, L. M., Clausen, B., Peters, E., and Gustard, A.: Hydrological drought characteristics, Chapt. 5, in: Developments in Water Science, 48, Elsevier Science B. V., Amsterdam, the Netherlands, 139-198, 2004. 
JRC: European Drought Observatory (EDO), Institute for Environment and Sustainability (IES), Joint Research Centre, European Commission, Ispra, Italy, available at: http://edo.jrc.ec.europa. eu/edov2/php/index.php?id=1000, last access: 20 June 2014.

Juen, I., Kaser, G., and Georges, C.: Modelling observed and future runoff from a glacierized tropical catchment (Cordillera Blanca, Peru), Mass Balance of Andean Glaciers, Global Planet. Change, 59, 37-48, doi:10.1016/j.gloplacha.2006.11.038, 2007.

Koboltschnig, G. R., Schöner, W., Holzmann, H., and Zappa, M.: Glaciermelt of a small basin contributing to runoff under the extreme climate conditions in the summer of 2003, Hydrol. Process., 23, 1010-1018, 2009.

Li, H., Beldring, S., and Xu, C.-Y.: Implementation and testing of routing algorithms in the distributed Hydrologiska Byråns Vattenbalansavdelning model for mountainous catchments, Hydrol. Res., 45, 322-333, 2014.

Marks, D., Kimball, J., Tingey, D., and Link, T.: The sensitivity of snowmelt processes to climate conditions and forest cover during rain-on-snow: a case study of the 1996 Pacific Northwest flood, Hydrol. Process., 12, 1569-1587, doi:10.1002/(SICI)10991085(199808/09)12:10/11<1569::AID-HYP682>3.0.CO;2-L, 1998.

Marsh, P. and Woo, M.: Snowmelt, glacier melt, and high arctic streamflow regimes, Can. J. Earth Sci., 18, 1380-1384, doi:10.1002/wea.67, 1981.

Merz, R., Parajka, J., and Blöschl, G.: Scale effects in conceptual hydrological modeling, Water Resour. Res., 45, W09405, doi:10.1029/2009WR007872, 2009.

Merz, R., Parajka, J., and Blöschl, G.: Time stability of catchment model parameters: implications for climate impact analyses, Water Resour. Res., 47, W02531, doi:10.1029/2010WR009505, 2011

Mishra, A. K. and Singh, V. P.: A review of drought concepts, J. Hydrol., 391, 202-216, doi:10.1016/j.jhydrol.2010.07.012, 2010.

Mohr, M. and Tveito, O.: Daily temperature and precipitation maps with $1 \mathrm{~km}$ resolution derived from Norwegian weather observations, 17th Conference on Applied Climatology, no. 6.3, 13 August 2008, Whistler, Canada, 2008.

Naz, B. S., Frans, C. D., Clarke, G. K. C., Burns, P., and Lettenmaier, D. P.: Modeling the effect of glacier recession on streamflow response using a coupled glacio-hydrological model, Hydrol. Earth Syst. Sci., 18, 787-802, doi:10.5194/hess-18-7872014, 2014.

NDMC: US Drought Impact Reporter (DIR), National Drought Mitigation Center, Lincoln, Nebraska, USA, available at: http: //public.droughtreporter.unl.edu/about/ (last access: 20 June 2014), 2014.

Nesje, A.: Briksdalsbreen in western Norway: AD 1900-2004 frontal fluctuations as a combined effect of variations in winter precipitation and summer temperature, Holocene, 15, 12451252, doi:10.1191/0959683605hl897rr, 2005.

Pal, I., Lall, U., Robertson, A. W., Cane, M. A., and Bansal, R.: Predictability of Western Himalayan river flow: melt seasonal inflow into Bhakra Reservoir in northern India, Hydrol. Earth Syst. Sci., 17, 2131-2146, doi:10.5194/hess-17-2131-2013, 2013.

Parajka, J. and Blöschl, G.: The value of \{MODIS $\}$ snow cover data in validating and calibrating conceptual hydrologic models, J. Hydrol., 358, 240-258, doi:10.1016/j.jhydrol.2008.06.006, 2008.
Parajka, J., Merz, R., and Blöschl, G.: Uncertainty and multiple objective calibration in regional water balance modelling: case study in 320 Austrian catchments, Hydrol. Process., 21, 435446, doi:10.1002/hyp.6253, 2007.

Parry, S., Hannaford, J., Lloyd-Hughes, B., and Prudhomme, C.: Multi-year droughts in Europe: analysis of development and causes, Hydrol. Res., 43, 689-706, doi:10.2166/nh.2012.024, 2012.

Paul, F., Machguth, H., and Kääb, A.: On the impact of glacier albedo under conditions of extreme glacier melt: the summer of 2003 in the Alps, EARSeL eProceedings, 4, 139-149, 2005.

Pfister, C., Weingartner, R., and Luterbacher, J.: Hydrological winter droughts over the last 450 years in the Upper Rhine basin: A methodological approach, Hydrol. Sci. J., 51, 966-985, 2006.

Ploum, S. and Van Loon, A.: Investigating seasonal variables for droughts in cold climates: a comparative study in Austria and Norway, DROUGHT-R\& SPI Technical Report No. 15, available at: http://www.eu-drought.org/technicalreports (last access: 18 September 2014), 29, Wageningen University, Wageningen, the Netherlands, 2014.

Prudhomme, C., Giuntoli, I., Robinson, E. L., Clark, D. B., Arnell, N. W., Dankers, R., Fekete, B. M., Franssen, W., Gerten, D., Gosling, S. N., Hagemann, S., Hannah, D. M., Kim, H., Masaki, Y., Satoh, Y., Stacke, T., Wada, Y., and Wisser, D.: Hydrological droughts in the 21st century, hotspots and uncertainties from a global multimodel ensemble experiment, Proc. Natl. Acad. Sci., 111, 3262-3267, doi:10.1073/pnas.1222473110, 2014.

Sælthun, N.: The Nordic HBV Model, Tech. rep., University of Oslo, Oslo, Norway, available at: http://folk.uio.no/nilsroar/ gf247/hbvmod.pdf (last access: 18 September 2014), 1996.

Scaife, A. A., Arribas, A., Blockley, E., Brookshaw, A., Clark, R. T., Dunstone, N., Eade, R., Fereday, D., Folland, C. K., Gordon, M., Hermanson, L., Knight, J. R., Lea, D. J., MacLachlan, C., Maidens, A., Martin, M., Peterson, A. K., Smith, D., Vellinga, M., Wallace, E., Waters, J., and Williams, A.: Skillful long-range prediction of European and North American winters, Geophys. Res. Lett., 41, 2514-2519, doi:10.1002/2014GL059637, 2014.

Schorer, M.: Extreme Trockensommer in der Schweiz im 20. Jh. und ihre Folgen für Natur und Wirtschaft, Geographica Bernensia G 40, Geographisches Institut der Universität Bern, Bern, Switzerland, Bern, 1992.

Sheffield, J. and Wood, E.: Drought; Past Problems and Future Scenarios, Earthscan, London, Washington DC, 2011.

Stahl, K., Blauhut, V., Kohn, I., Acácio, V., Assimacopoulos, D., Bifulco, C., De Stefano, L., Dias, S., Eilertz, D., Frielingsdorf, B., Hegdahl, T., Kampragou, E., Kourentzis, V., Melsen, L., Van Lanen, H., Van Loon, A., Massarutto, A., Musolino, D., De Paoli, L., Senn, L., Stagge, J., Tallaksen, L., and Urquijo, J.: A European Drought Impact Report Inventory (EDII): Design and Test for Selected Recent Droughts in Europe, DROUGHTR\& SPI Technical Report No. 3, 23, available at: http://www. eu-drought.org/technicalreports/3 (last access: 18 September 2014), Wageningen University, Wageningen, the Netherlands, 2012.

Stewart, I. T.: Changes in snowpack and snowmelt runoff for key mountain regions, Hydrol. Process., 23, 78-94, doi:10.1002/hyp.7128, 2009.

Tallaksen, L. M. and Van Lanen, H. A. J. (Eds.): Hydrological Drought: Processes and Estimation Methods for Streamflow and 
Groundwater, Developments in Water Science; 48, Elsevier Science B.V., Amsterdam, the Netherlands, 2004.

Thayyen, R. J. and Gergan, J. T.: Role of glaciers in watershed hydrology: a preliminary study of a "Himalayan catchment", The Cryosphere, 4, 115-128, doi:10.5194/tc-4-115-2010, 2010.

Van Loon, A. F.: On the Propagation of Drought. How Climate and Catchment Characteristics Influence Hydrological Drought Development and Recovery, $\mathrm{PhD}$ thesis, Wageningen University, Wageningen, the Netherlands, available at: http://edepot.wur.nl/ 249786, last access: 28 May 2013.

Van Loon, A. and Laaha, G.: Hydrological drought severity explained by climate and catchment characteristics, J. Hydrol., doi:10.1016/j.jhydrol.2014.10.059, in press, 2014.

Van Loon, A. F. and Van Lanen, H. A. J.: A process-based typology of hydrological drought, Hydrol. Earth Syst. Sci., 16, 19151946, doi:10.5194/hess-16-1915-2012, 2012.
Vidal, J.-P., Martin, E., Franchistéguy, L., Habets, F., Soubeyroux, J.-M., Blanchard, M., and Baillon, M.: Multilevel and multiscale drought reanalysis over France with the Safran-Isba-Modcou hydrometeorological suite, Hydrol. Earth Syst. Sci., 14, 459-478, doi:10.5194/hess-14-459-2010, 2010.

Weingartner, R., Blöschl, G., Hannah, D., Marks, D., Parajka, J., Pearson, C., Rogger, M., Salinas, J., Sauquet, E., Srikanthan, R., Thompson, S., and Viglione, A.: Prediction of seasonal runoff in ungauged basins, Chapt. 6, in: Runoff Prediction in Ungauged Basins - Synthesis across Processes, Places and Scales, edited by: Blöschl, G., Sivapalan, M., Wagener, T., Viglione, A., and Savenije, H., Cambridge University Press, New York, USA, 102 135, 2013.

Wilhite, D. (Ed.): Drought: a Global Assessment, Vol. I \& II, Routledge Hazards and Disasters Series, Routledge, London, 2000.

Wilhite, D. A. and Glantz, M. H.: Understanding the drought phenomenon: the role of definitions, Water Int., 10, 111-120, 1985. 